\title{
CONSTITUTIONAL PROTECTION OF FREEDOM OF EXPRESSION IN THE FIRST DECADE OF THE FUNDAMENTAL LAW OF HUNGARY*
}

\author{
András Koltay \\ Professor of Law \\ (University of Public Service \& Pázmány Péter Catholic University)
}

\section{Initial remarks}

This paper aims to trace the changes in the case-law of the Constitutional Court of Hungary $(\mathrm{CCH})$ related to freedom of expression under the scope of the Fundamental Law, in the light of the decisions made since 1 January 2012. Of course, the case-law of the $\mathrm{CCH}$ is only one of the important factors to consider when identifying the legal limits of freedom of expression, no matter how important it is, yet it is one which, in itself, says a great deal about the constitutional culture of a state, its perception of its legal system in terms of fundamental rights, and its ability to influence both legislation and the courts' application of law.

The Constitutional Court of Hungary can exercise such influence much more effectively within the scope of the Fundamental Law: Following the introduction of the constitutional complaint, it reviews whether individual judicial decisions are in accordance with the Fundamental Law [Article 24(2)d]. The introduction of this new competence has led to expansive growth in the CCH's case-law in certain areas, with the result that a number of issues that it was not allowed to examine previously in the context of abstract norm control have been brought before the Court. Nevertheless, it is important to bear in mind that the CCH's competence does not cover the 'correctness' of the court decisions under review, but the constitutional compatibility of the set of criteria applied by the courts in the decision; the $\mathrm{CCH}$ is therefore not another forum for appeal but the guardian of judicial deliberation, as required by the Fundamental

\footnotetext{
* The author would like to thank the valuable comments, suggestions and support of Tamás Szikora, Zsolt Szomora, András Téglási, Bernát Török and Erzsébet Xénia Udvari. Thanks are also due to Édua Reményi, who did a sterling job editing my earlier manuscript.
} 
Law. Analysing the statements of reasons for some of the resolutions discussed below will reveal how difficult it is to walk this narrow plank, making sure that the Panel only sets the constitutional framework for the courts' decision-making, leaving the application of discretion that stems from the facts of the case up to the courts rather than deciding for them.

Importantly, the Fundamental Law marked a new era for the constitutional caselaw only partially and following Constitutional Court Decision 13/2013. (VI. 17.) AB, earlier $\mathrm{CCH}$ decisions that ceased to be in effect may remain authoritative. According to this decision, if the relevant provision of the Fundamental Law has the same or similar content as the former Constitution and the use of the arguments, legal principles and constitutional contexts contained in the previous resolution is justified by the body in due detail, then previous case law can be referred to and earlier decisions remain authoritative (Paragraphs 28-34). This review, however, will only refer to $\mathrm{CCH}$ decisions from before 2012 in the most justified cases, when it is necessary to understand the changes brought about by recent decisions. Our review cannot strive for completeness; for example, a large proportion (but not all) of the decisions taken during the election campaign are ignored, ${ }^{1}$ but I will still try to provide a thorough and comprehensive overview of the CCH's case-law related to freedom of expression. The guiding thread against which we try to measure this case-law is the objective of striking a balance between the freedom of public communication and the protection of human dignity which it is capable of violating. This may be a mirage in practice because, in individual cases, since they have to be decided one way or another, such a balance cannot conceptually exist: Either the protection of freedom or the protection of dignity will prevail. Overall, however, the case-law as a whole may endeavour to strike a balance between these two competing values, securing both of them in parallel and limiting their validity. By the end of this review, I hope to have outlined how successful this balancing act - the task which the $\mathrm{CCH}$ has been mandated with - has been thus far.

\section{Article IX of the Fundamental Law}

Articles IX(1) and IX(2) of the Fundamental Law provide for freedom of expression and freedom of the press, while the current Paragraph 6 (originally Paragraph 3 at the time of its adoption) provides for the fundamental nature of certain related regulatory issues. Comparing these provisions with Article 61 of the Constitution effective before the summer of 2010, some significant differences can be discerned, but if Article IX is set alongside, the text of the law which was in force during the year and a half between the Summer of 2010 and 1 January 2012, the differences are no longer as striking. Since the Summer of 2010, with regard to freedom of the press, the diversity of the press and

On them, see BADÓ, Katalin - LovASSY, Ádám - TÉGLÁsI, András: Az Alkotmánybíróság választásokkal kapcsolatos joggyakorlata (1990-2017). In: TÉGLÁsI, András (ed.): Tanulmányok a választójog, a választási rendszerek és a népszavazás aktuális kérdéseiröl. A Választás és Demokrácia Ludovika Kutatócsoport kutatási eredményei (2017-2018). Budapest, Dialóg Campus, 2019. 303-470. 
ensuring free information about the democratic public have been fixed as additional obligations of public bodies in the constitutional texts. ${ }^{2}$

The current Paragraphs 3-5 of Article IX of the Fundamental Law were inserted into the text subsequently, in 2013, and served to provide a constitutional underpinning for specific legislative needs, and therefore do not affect the interpretation of freedom of expression in general. Paragraph 3 provides for the free distribution of political advertisements during election campaign periods; Paragraph 4 states that the exercise of freedom of expression may not be aimed at violating human dignity, while Paragraph 5 seeks to lay down constitutional foundations for the enforcement of private law claims connected to hate speech against certain communities.

While Paragraph 3 was annulled by Decision 1/2013. (I. 7.) AB during the preliminary norm control of the Act on the election procedure, adopted by the Parliament on 26 November 2012, Paragraphs 4 and 5 can be regarded as reflections of previous $\mathrm{CCH}$ case-law related to hate speech, and the rule of dignity set out in Paragraph 4 also applies in matters with personal rights relevance. However, as Zsolt Szomora points out in connection with Decision 1/2015. (I. 16.) AB, the outcome of balancing the freedom of expression with the protection of dignity may be the same as under the new text of the Constitution, even without the new text of Article IX(4), ${ }^{3}$ due to the previous case-law of the $\mathrm{CCH}$, and his observation is, in my view, of general application, going beyond the decision that he analysed. Paragraph 5 clearly serves as a constitutional underpinning of the Civil Code provisions, also adopted in $2013 .{ }^{4} \mathrm{All}$ in all, the question is the extent to which the text of the Fundamental Law influences the case-law of the $\mathrm{CCH}$ or, more broadly, jurisprudence; and in the following paragraphs we may perhaps come closer to answering it.

\section{Scope and protection of the freedom of expression}

Decisions that address the issue of the scope of freedom of expression form an important subset of recent $\mathrm{CCH}$ case-law. ${ }^{5}$ The task facing the legal system is to distinguish between the range of the freedom of expression (scope) and the strength of the protection of speech that falls within its scope. If an expression or act falls outside the scope of freedom of expression, the possibility of its constitutional protection does not even come into question. If, on the other hand, an expressive act does fall within its scope, it can be examined whether it is covered by the constitutional protection of the

2 See Koltay, András: Az Alkotmány új 61. §-a. A vélemény- és a sajtószabadság új ruhában. Közjogi Szemle, 2010/3. 1-9.

3 Szomora, Zsolt: A véleményszabadság büntetöjogi korlátai az Alaptörvény hatályba lépése után, különös tekintettel a becsületvédelemre. In: BALOGH, Elemér (ed.): Számadás az Alaptörvényröl. Budapest, Magyar Közlöny Lap- és Könyvkiadó, 2016. 535.

4 Háttéranyag az Alaptörvény negyedik módositásához. tinyurl.com/5eycz72t, 18-19.

5 For an analysis of the Constitutional Court's pre-2018 case-law, see TöröK, Bernát: A közlések alkotmányos alapértéke a szólásszabadság magyar koncepciójában. In: KoLTAY, András - TöRöK, Bernát (eds): Sajtószabadság és médiajog a 21. század elején 2. Budapest, Wolters Kluwer, 2015. 203-224. 
fundamental right. The definition of limitations on freedom of expression may only be interpreted in the context of cases that qualify as the exercise of a fundamental right.

An example of this is Decision 3132/2018. (IV. 19.) AB, which stated that any conduct constituting an offence of vandalism could also fall under the scope of freedom of expression. The petitioner painted on a tarpaulin owned by a construction company working on the erection of the statue next to the monument to the German occupation, erected in Szabadság Square in Budapest, and this 'conveyed the petitioner's opinion that he did not agree with the erection of the said monument' (Paragraph 36). However, according to the Panel, the protection of the company's property rights in the specific case provides a basis for restricting the freedom of expression, even though the latter concerned a public matter (Paragraphs 39-42).

In Decision 1/2019. (II. 13.) AB, however, the Panel considered pouring paint on the Soviet war memorial, also in Szabadság Square, to fall outside the scope of freedom of expression. This act was committed after a lawful demonstration, and was presumably intended to protest against the negotiations and rapprochement between the Hungarian and Russian governments. However, the uncertainty surrounding the assessment of conduct that is undoubtedly expressive also established a basis for the Panel to find that it fell outside the scope of freedom of expression (Paragraphs 44 and 45). In this decision, the $\mathrm{CCH}$ arrived at important conclusions regarding the scope of freedom of expression, which can be summarised as follows:

- freedom of expression may extend to communications to the public only (Paragraph 29);

- a physical - that is, non-verbal - expression may also qualify as an expression of opinion (Paragraph 30);

- freedom of expression does not extend to speech in the everyday sense, but it must be examined which acts are connected with the constitutional justification of the fundamental right, the values of self-expression and democratic publicity (Paragraph 31);

- the perpetrator must be acting with the intention of expressing his opinion (Paragraph 36);

- 'the chosen form of communication may be considered an objectively suitable means or mediator to communicate thoughts' (Paragraph 36);

- the act must be a 'communication that may be interpreted in public', that is members of the public must understand that it is the actual communication of an opinion (Paragraph 44).

The above set of criteria is a significant step forward in the conceptual clarification of the boundaries of freedom of expression, but two elements of it are arguable. On the one hand, it is unclear whether freedom of expression really only protects communications made in front of the public; this restriction does not follow from the Fundamental Law. A protected opinion may also appear in a private letter or in a conversation within a narrow circle. On the other hand, although the statement of reasons for the $\mathrm{CCH}$ decision does not state its position on that question with complete precision, it can be concluded that the Panel only considers those expressions as being within the scope of freedom of expression which meet two conditions: They can be identified as an opinion, and their content and message are understood by those who 
perceive it. The $\mathrm{CCH}$ regarded the legal interpretation of the appellate court that acted in the case earlier as being in line with the applicable constitutional criteria (Paragraph 45): The Court made it clear that it did not consider the demolition of the monument to be within the scope of freedom of expression because it considered it necessary that the act's meaning, motivation and purpose be interpretable for observers (Paragraph 5). In my view, this is a mistake. Numerous examples can be taken from the history of art and literature of the contemporary audience being at a loss when faced with the meaning and message of works of art or literary works. ${ }^{6}$ For conduct to be covered by freedom of expression, it seems to suffice that it may be interpreted as an opinion, while the content of the opinion being understood is not a requirement. In the specific case at hand, it is not disputed that the protester wanted to express something, even if it was not quite clear what. At the same time, the protection of the property and civil right to respect for the deceased related to the monument may justify a restriction even against an act interpreted within the scope of freedom of expression. ${ }^{7}$

However, according to Decision 14/2019. (IV. 17.) AB, inscriptions and colourings made on a road or pavement section that qualifies as a public area, using an easily removable paint, may qualify as manifestations falling within the scope of the right to express an opinion. The painting in question was made by an opposition political party in protest at the neglected condition of the pavements. "The specific act was therefore, according to the objective assessment, a communication that could be interpreted by the public" (Paragraph 36). The majority of the Panel also enriched the constitutional case-law on freedom of expression with an important additional aspect: as the statement of reasons noted, "a decent sense of humour on behalf of the acting bodies is also necessary when considering any act” (Paragraph 36).

Constitutional Court Decision 3089/2019. (IV. 26.) AB also concerned the scope of freedom of expression. The petitioners placed a small block of wood, wrapped in paper, in the customer area of several banks, on one side of which was written "Enough of the looting! Turn over", with the other side bearing an excerpt from a poem by Sándor Petöfi (Hungary's revolutionary poet from the nineteenth century), entitled The Sea has Risen... (the text of the poem only became visible if the package was picked up and turned on its back). The Court considered this act to fall within the scope of freedom of expression (Paragraph 32). People present at the bank might believe that the pieces of wood placed there were explosives, so the act was classified as a public threat by the courts. On the issue of the protection of freedom of expression, the justification for the CCH's decision is somewhat liable to misinterpretation. According to the Panel, 'despite the petitioners' act having an identifiable message to be communicated, it

I also consider the scope of freedom of art and freedom of expression to be identical within the Hungarian legal system, despite their separate naming in the Fundamental Law, so this example may be relevant on this ground. On this, see KoLTAY, András: Dorian Gray képmásához való jog: a mủvészet szabadságának önálló alapjogi jellegéröl. In: KolTAY, András - TöRÖK, Bernát (eds): Sajtószabadság és médiajog a 21. század elején 3. Budapest, Wolters Kluwer, 2016. 53-99.

7 For an analysis of the decision, see MészÁRos, Ádám Zoltán: Szimbolikus szólás kontra dologrongálás. Azaz a véleménynyilvánítás szabadsága és a tulajdonhoz való határvitája büntetőjogi szempontból. Jogtudományi Közlöny, 2020/2. 74-78. 
could not be considered a protected exercise of fundamental rights as a whole, as the message of the petitioners' act could not be identified by the outside observer, since the act at hand violated a constitutionally protected value, namely the maintenance of public security' (Paragraph 38). It follows that the nature of the opinion of the act could not be understood by those present, that is according to the statement of reasons for Decision $1 / 2019$. (II. 13.) AB, it could not qualify as covered by freedom of expression. Moreover, the conduct examined in the latter case failed to meet two criteria from the outset, which could be deduced from the earlier decision: It could not be interpreted as an opinion, and in this context the content of the opinion could not be understood by those present. This contradiction will need to be clarified in later decisions. In my view, the existence of only one of the first two criteria is necessary for it to be covered by freedom of expression: The perception that an expression has the nature of an opinion is important, but understanding the content of the opinion is not.

\section{Protection of personality rights and debates on public affairs}

The extent of the protection of the individual's rights - thanks to the possibility of the constitutional complaint, that is designed to defend constitutionality against personal injuries caused by ordinary courts' decisions - is the most frequently encountered problem touching the limits of freedom of expression in the case-law of the $\mathrm{CCH}$. The issue is complex: Disputes can be brought before the $\mathrm{CCH}$ through both private law and criminal law proceedings, following the application of several facts in both branches; what is more, two new codes were enacted or entered into force during the period under review.

\subsection{Provisions of the new Civil Code and Criminal Code}

The Fundamental Law, like the former Constitution, not only declares freedom of expression but also the protection of reputation and privacy to be a fundamental right. However, the second sentence of Article VI(1) stating this has had a stronger wording since 2018: "Everyone has the right to respect for his or her private and family life, home, communications and reputation. Exercising the right to freedom of expression and assembly shall not impair the private and family life and home of others." For the time being, this provision has not brought about any change in the CCH's case-law regarding the rights of the individual, as the impact of the legislative changes introduced by the two new legal codes since 2012 may be deemed marginal. The statutory elements in Act $\mathrm{C}$ of 2012 on the Criminal Code banning defamation and libel (Articles 226 and 227) were taken over from the previous Criminal Code word-for-word. ${ }^{8}$ Act V of 2013 on the Civil Code includes the statutory elements of the violation of the right to honour, unlike its 1959 predecessor, which have been crystallised in case-law [Article 2:45(1)], and amended to a lesser extent the rules on the protection of image (Article 2:48). The

For a comprehensive and comparative analysis of the statutory elements of defamation and libel, see Tóтн, J. Zoltán: A büntetőjogi rágalmazás és becsületsértés. Budapest, MTMI, 2017. 
specific protection of the right to privacy constituting a substantive change in the field of private law can be found in Article 2:43(b), as well as in Article 2:44, which is a generic clause aiming to secure the freedom of debate on public affairs and at the same time to restrict the protection of public actors' personality rights. In connection with the latter, Decision 7/2014. (III. 7.) AB was a key decision for the subsequent $\mathrm{CCH}$ case-law.

However, upon the adoption of the Civil Code, Article 2:44 read as follows: "The exercise of the fundamental rights ensuring a free discussion of public affairs in the legitimate interest of the public may limit the protection of the personality rights of public figures to an extent that is necessary and proportionate and is without prejudice to human dignity." The Commissioner for Fundamental Rights contested the wording of the 'legitimate public interest' provision, stipulated as one of the preconditions for the reduced protection of personality rights, prior to the entry into force of said provision, via a motion to the $\mathrm{CCH}$. Following this, the $\mathrm{CCH}$, in Decision 7/2014. (III. 7.) $\mathrm{AB}$, deleted the text concerned. The decision stated that although the protection of human dignity can constitute a limitation on the freedom of expression, nevertheless, any violation of human dignity "cannot justify the restriction of freedom of expression. If it were to the contrary, the very content of the freedom of expression would become void. [...] The right to the protection of human dignity is unrestrictable, but only as a legal determinant of human status" (Paragraph 43).

The constitutional problem and the quite narrow latitude available for the $\mathrm{CCH}$ can easily be discerned. Article II of the Fundamental Law and Article 2:42(2) of the Civil Code expressly protect human dignity, the former also declaring its inviolability, although this does not mean it is unrestrictable. The freedom of expression, similarly to human dignity, is a constitutional right which is not unrestrictable, but whose restriction is available only within a limited scope, similarly to all other fundamental rights.

The constitutional collision of human dignity and freedom of expression is not a recent problem. Article 2:44 of the Civil Code aims to provide extra protection for the freedom of expression (by ensuring a wider freedom for discussing public affairs), among other things, by prohibiting the publication of opinions violating human dignity, as one of the objective limitations on a wider protection. Accordingly, if we assume that the latter provision does not render exercising the freedom of expression impossible (since any injurious opinion may at the same time necessarily violate human dignity, so it could be sanctioned), then a constitutional interpretation must be assigned to the protection of human dignity, in terms of the application of the examined provision, which can provide guidance for those applying the law. ${ }^{9}$

The decision states that "the unrestrictable aspect of human dignity constitutes the absolute limit of the freedom of speech only with respect to that extremely narrow range of expressions of speech which deny the very foundations of the human status" (Paragraph 61). As a general rule, opinions and value judgements cannot be grounds for

See Koltay, András: Az ,általános személyiségi jog” azonosítása felé. Alkotmányjogi, magánjogi és büntetőjogi vizsgálódás. In: Koltay, András - TöRöK, Bernát (eds): Sajtószabadság és médiajog a 21. század elején 4. Budapest, Wolters Kluwer, 2017. 267-296. 
either criminal or civil law prosecution; in this respect the decision referred to one of the most important elements of Decision 36/1994. (VI. 24.) AB: the requirement of total impunity for defamatory opinions. However, as opposed to the decision of 1994, in 2014 the $\mathrm{CCH}$ did not consider these value judgements to be constitutionally protected all the time. As the statement of reasons explains, ensuring the freedom of debating public affairs in public:

"Does not result in the protection of human dignity, privacy and reputation of the parties concerned [...] becoming void. Persons exercising state powers and politicians acting in public are entitled to the protection of their personality rights if the given value judgement relating to their person does not concern their public affairs-related activity, within the scope of a discussion of public affairs, but their private or family life. Hence, civil law prosecution might be justified in that narrow scope when the expressed opinion, being a total, obvious and seriously disparaging negation of the human status of the person concerned, violates not the personality rights named under Article 2:43 of the new Civil Code, but the unrestrictable aspect of human dignity specified under Article 2:42. Taking into account the arguments detailed above, even public figures can demand legal protection against false statements of fact." (Paragraph 62)

In this way, the Panel also responds to the question of the constitutional interpretation of Article IX(4) of the Fundamental Law, according to which "the exercise of the freedom of expression may not aim to violate the human dignity of others". Based on the interpretation of the $\mathrm{CCH}$ summarised above, this constitutional provision cannot be regarded as an absolute limit on the freedom of expression.

One of the merits of the decision is that it attempts to provide an independent interpretation of the personality right of human dignity, which so far has only been used in the application of the law in a very fragmentary manner. In this respect, the following conclusions can be drawn from the decision of the Constitutional Court:

- opinions and value judgements concerning public affairs and public figures enjoy special protection,

- such protection does not, however, extend to value judgements made regarding the private or family life of public figures (as long as these are not related public affairs),

- furthermore, the protection does not include those opinions which represent an obvious and seriously disparaging negation of the human status of the person concerned (that is if an opinion questions or doubts that the person concerned is a human being, or disparages or reviles the person concerned in respect of their human quality and not in relation to public affairs).

In the latter case, it is not the right to honour as per Article 2:45 of the Civil Code that is violated (the protection granted to opinions relating to public affairs under Article 2:44 may also totally exclude the possibility of violating this right to honour with regard to outstanding public figures such as politicians and persons exercising state powers, but the right to human dignity [Article 2:42(2) of the Civil Code]. In other words, based 
on the decision of the $\mathrm{CCH}$ - contrary to the former approach of civil law courts human dignity has a unique and independently applicable content, above and beyond the right to honour and reputation. At the same time, this means supplementing and rejecting the stipulations of the decision of 1994, as they relate to the comprehensive and total protection of opinions and their unrestrictability.

As regards statements of fact, the decision found that "demonstrably false facts in themselves are not protected by the constitution" (Paragraph 49), thereby making a vague hint that in certain cases even false statements of facts can receive protection under freedom of expression. In the following paragraph, the decision establishes that "even for those facts having no constitutional value which later turn out to be false, it is justified to take into account the interest of ensuring as free conditions for discussion of public affairs as possible, when determining the extent of imputability and the possible penalties in the course of legal proceedings" (Paragraph 50). However, the wording 'legitimate public interest' represents an unnecessary restriction of the freedom of expression and freedom of the press, since "[a]s far as the discussion of public affairs is concerned, the restriction of the protection of personality rights of public figures for the purpose of guaranteeing freedom of expression is a constitutional interest and requirement in any case" (Paragraph 65), which allows freedom of expression "to be restricted only in order to protect another fundamental right or a constitutional value. Pursuant to the new Civil Code, an imprecisely specified and named 'reasonable public interest' does not fall within this range" (Paragraph 66).

\subsection{Public affairs and public figures}

The Constitutional Court of Hungary case-law of the last decade and the case-law emerging today reinforce the interpretation that the 'public nature' of an opinion is the primary consideration in determining whether the scope of personal protection will be reduced, rather than the status (or lack thereof) of the person referred to by the communication. However, the case-law is not completely free of contradictions, and this introduces an element of uncertainty for those seeking a clear response. ${ }^{10}$

Constitutional Court Decision 7/2014. (III. 7.) AB stipulates the primacy of identifying that an expression concerns public affairs, although it also indicates that the status of the public figure is important too, but it is secondary to the public nature of communication when establishing the scope of the protection of personality rights. Public affairs have an impact on the enforcement of the personality rights of those concerned, and if the affected individuals also qualify as public figures their rights might be narrowed down even further; the scope of this limitation depends on the nature of their status as public figures (from politicians to celebrities).

10 For the related case-law of the $\mathrm{CCH}$ see also BALOGH, Éva: A megkülönböztetés művészete: bírói mérlegelés a közszereplőkkel kapcsolatos közlések szabadsága kapcsán. Fundamentum, 2016/1. 22-38.; BALOGH, Éva: Alkotmánybíróság útvesztőben. Fundamentum, 2018/2-3. 80-99. 
"The judiciary must take into account first and foremost the fact that, since it is public affairs themselves and not public figures that can be found in the focus of the freedom of political speech, all speeches related to public affairs are under extra protection, which restricts the protection of the personality rights of those affected by them. This means that the restricted character of the protection of personality rights applies not only to those who are professionally engaged in public appearance, as debating public matters can affect a wider scope of individuals in the framework of a concrete debate in a society. However, the status of the person affected by the speech must also be taken into account: in the case of persons exercising state powers and public actor politicians, the restricted nature of the protection of their personality rights is considered 'necessary and proportionate' to a wider extent than with regard to any other person.” (Paragraph 57)

This approach is reinforced by Decision 14/2017. (VI. 30.) AB:

"[T]he activity which is the basis of the labour dispute, that is the content of the Internet portal and the texts published there, are predominantly of a professional nature and do not show any link to public affairs, which would render this activity clearly as one that belongs to the freedom of discussing public affairs." (Paragraph 40)

Based on Decision 8/2018. (VI. 5.) AB, even when expressing opinions on persons who hold high level positions in the Church, the connection of the speech act to public affairs determines the standard applicable to the personal rights of those concerned, and as such it is irrelevant that they do not exercise public authority and are not politicians (Paragraphs 20-25). As a general rule, allegations concerning a local government notary cannot be excluded from the scope of the debate on public affairs, since "manifestations concerning the personality and credibility of public figures generally fall within the protected scope of the debate on public affairs" [3263/2018. (VI. 20.) $\mathrm{AB}$, Paragraph 43]. Information and images published about a holiday enjoyed by a political adviser may also constitute a contribution to the public debate, and even public discourse on the existence or absence of a figure's public status is itself a public debate, so applying reduced personality protection is constitutionally justified [26/2019. (VI. 23.) AB, Paragraphs 29-34]. In the criminal proceedings relating to the main case underlying Decision 3030/2019. (II. 13.) AB, the accused person repeated and indeed elaborated on his opinion of the complainant before the court, expressing new, strongly critical value judgements ('heap of shit', 'shame, blight on civilisation', 'public ghoul'). In the main case, he was sentenced for libel, but in the new case launched due to the publication by the accused of the expressions he used at the trial - on his own social media accounts - he was acquitted by the Court. The Constitutional Court of Hungary rejected the constitutional complaint lodged on this ground on the basis that information on criminal proceedings qualifies as a public affair (Paragraphs 38-40).

However, as the two decisions demonstrate, the case-law of the $\mathrm{CCH}$ is not completely free from contradictions. In the case preceding Decision 1/2015. (I. 16.) AB, 
the contested opinions were expressed in a private debate and as such the test applicable to discussing public affairs did not have to be applied in this case. It is therefore also questionable why the $\mathrm{CCH}$ did not examine the context of the contested opinion in the first place, instead focussing on the status of the injured person. With respect to the fact that the injured party worked as a lawyer, the $\mathrm{CCH}$ concluded that a "person acting as a lawyer may not be considered a person exercising state powers solely due to his status as a lawyer, neither does he qualify as a public figure politician" (Paragraph 39). It follows indirectly that, following Decision 7/2014. (III. 7.) AB, deviating from the reasons for its decision, it turned back to the narrower definition of a public figure found in Decision 36/1994. (VI. 24.) AB, although it is necessary not only to examine primarily the status of the person but also the 'public affairs' nature of the case in which the contested opinion was delivered. The statement of reasons for Decision 3145/2018. (V. 7.) $\mathrm{AB}$ somewhat confuses the relationship of considerations relating to public affairs and those concerning public figures:

"If the public speech affects the freedom of debating public affairs, it is necessary to further examine whether or not the person affected by the speech is a public figure in the given situation, and only after this examination can the constitutional test be applied. The fact that a public speech is related to public affairs per se shall not automatically lead to reduced protection of the personality rights of the persons concerned. Establishing the public figure's status always achieved by a case-by-case evaluation. [...] However, the subject matter of the speech (the public affair) is not the only criterion when judging the status of those affected by a public statement or speech. It is also indispensable to examine whether the person concerned decided in a voluntary manner to become someone who has an influence on public affairs. The enforcement of the right to free expression may be justified exclusively in cases in which the participants became more active shapers of public affairs based on their own decisions, and thereby accepting their exposure to evaluations and judgements in the public eye in the community concerned. Therefore, they are obliged to have an increased threshold of tolerance in respect of speeches and opinions in the context of the debates on public affairs that concern them, or classify them or which attack their personality." (Paragraphs 44 and 48)

The statement of reasons, beyond making an erroneous judgement of the relationship between the criteria of a public affair nature and public figure status, accepts the approach taken by the Hungarian Supreme Court (Kúria), in cases concerning images of policemen, according to which "based on the definition of jurisprudence and legal literature, appearance, more specifically public appearance, shall be any political, social or artistic activity based on the voluntary decision and autonomous decision of the individual for a specific purpose, wishing to influence the life of the local community or society, in a narrower or broader sense." ${ }^{\prime 11}$ In the decisions taken in cases concerning

11 BKMPJE decision no $1 / 2012$, para III. 
the images of policemen, the $\mathrm{CCH}$ eventually avoided rebutting the necessarily voluntary nature of appearance in public, and did not consider the reduced right of policemen to the protection of their images as justified pursuant to Article 2:48(2) of the Civil Code describing an appearance in public life, but it based these decisions on the constitutional consideration of public interest (see below in more detail). This does not mean that this approach, according to which appearance in public is always based on a voluntary decision, is clearly wrong and overly restrictive, as is highlighted in the concurring opinion of CCH Judge Balázs Schanda, who refers to an example from the case-law of the European Court of Human Rights (ECtHR) as an illustration:

"It has already been confirmed by domestic case-law that the increased protection of the freedom of speech is applicable to a broader spectrum than 'official public figures' only [see 7/2014. (III. 7.) AB]. The guidance of the Strasbourg case-law sheds light upon the fact that, in certain cases, specific standards may be applied without having to identify any condition or circumstance which would render those concerned at least ad hoc voluntary public figures: The Norwegian seal hunters in the case previously referred to did not have the faintest intention of voluntarily making a public appearance or becoming affected in a public debate and yet the protection of their personality rights in the legitimate social debate on the cruelty of seal hunting became more restricted (Bladet Tromsø and Stensaas v. Norway, no 21980/93, judgment of 20 May 1999). It is a different question that the protection of personality rights may be restricted to a varying degree depending on those concerned, but this is already the question of tests within the realm of the debate of public affairs and it is not an evaluation for delineating the freedom of speech area which is to be granted increased protection." [3145/2018. (V. 7.) AB, Paragraph 105]

\subsection{Protection of reputation and honour - facts and opinions}

Pursuant to Decision 36/1994. (VI. 24.) AB, when judging statements liable to damage an individual's reputation and honour, a distinction needs to be made between statements of fact and statements of opinion. Further criteria are also applied to make this distinction. This is enshrined in the Civil Code; as such, pursuant to Article 2:45, violation of reputation means, specifically, misrepresenting or reporting untrue facts concerning and offending another person or misrepresenting true facts. Constitutional Court Decision 7/2014. (III. 7.) AB also stipulates that the freedom to state untrue facts and extreme opinions and their restrictability is to be established through the application of various constitutional tests.

According to the CCH's decisions with regard to statements of fact, a distinction must be made between true (proved before the court) statements of fact and untrue (unproven) statements of fact. A further distinction may be drawn in the context of untrue statements of fact stemming from differing evaluations of intentional statements, or statements where the speaker failed to exercise the caution reasonably expected of them pursuant to the rules applicable to their profession or occupation, and statements made while they observed the rules of their profession. Although the decisions of the 
$\mathrm{CCH}$ did not prescribe that such distinctions be made, the jurisprudence does make a distinction between opinions based on facts and opinions, which, due to their character, lack such a basis - opinions generated by passion, reflecting emotions or containing an individual subjective value judgement. If, in the case of the former, the veracity of the facts which serve as the grounds for an opinion, is proved before the courts, the person expressing the opinion shall not be prosecuted, no matter how extreme or offensive his opinion is. On the other hand, opinions which have no factual grounds will remain restrictable if they are unduly offensive, insulting and humiliating (disparaging), as described by the traditional judicial terminology.

The Constitutional Court of Hungary, in Decision 13/2014. (IV. 18.) AB, established criteria with a general scope and beyond the boundaries of criminal law, based on which the courts must take into account the following factors when differentiating between statements of fact and statements of opinion in cases of defamation:

"The proceeding courts need to respond to the question whether an opinion piece qualifies as a statement of fact or a value judgement. In the course of this, attention must be paid to the fact that the incriminating sentence has its full meaning in the context of a full text, the objective of which was to criticise the asset management case-laws of the municipality that is the writing criticised the asset and financial management of the city with irony and exaggeration as tools. Furthermore, it is necessary to evaluate the opinion context of the article, which drew public attention to material inequalities and wasteful budgetary management experienced within the local community. On the basis of this, the question can be decided as to whether the article contains any specific element at all, the truthfulness of which may be verified, or whether the writing is a value judgement expressing criticism, the opportunity and fact of which is protected, irrespective of its content." (Paragraph 49)

The above set of criteria is also applicable in private law disputes. Even taking into account all of the above, making a distinction between statements of fact and statements of opinion can be a daunting task in specific cases. The Constitutional Court of Hungary faced such a daunting differentiation task in a debate between two historians [3001/2018. (I. 10.) AB]. The defendant in the main proceedings stated that what the complainant said is "extreme right-wing political provocation, which [...] would be punishable with lawful means, because it relativises the Holocaust and it is on the verge of Holocaust denial." The complainant has "two fundamental objectives in mind: [...] they are related to the new ideological considerations of the new [...] institution; the new authoritarian regime needs to whitewash its predecessor, the Horthy regime. It is absolutely obvious that this is what the issue is about and it tries to whitewash even [Miklós] Horthy (the governor of Hungary between 1920 and 1944) himself from the crime of genocide but it is an impossible endeavour." The defendant, referring to the complainant, claimed that "only people who are professionally, morally and politically open to the extreme right and (who) ideologically think in terms of the restoration of the Horthy regime may be appointed as directors of such government institutes." These sentences fall half-way between a statement of facts and a statement of opinions and the $\mathrm{CCH}$ itself was divided 
on the issue of how to classify the statements made. However, the majority regarded them as opinions. The element of criticism and the nature of the judgement made the statement an opinion according to the majority of the $\mathrm{CCH}$ and, as such, a less stringent test had to be applied to it; the constitutional complaint was rejected by the body.

Constitutional Court Decision 3145/2018. (V. 7.) AB stated, with respect to a legal dispute between two figures in the tabloid press, that calling someone a 'psychopath' in a debate is not a statement of fact as long as the speaker is not using the term in a medical sense but as a colloquially accepted characterisation (Paragraph 81). According to Decision 3374/2019. (XII. 19.) AB, a statement made during a parliamentary debate that the Governor of the National Bank of Hungary (MNB) "stole public money with his family by setting up MNB foundations" (Paragraph 2) is not a statement of fact but an opinion (Paragraph 32) and, furthermore, it is of a kind that the person concerned must tolerate. (It should be noted that two constitutional court judges out of the five-member chamber disputed this interpretation and would have supported the classification of the contents of the quoted text as statement of fact.)

\subsection{Protection of reputation and honour - the threshold for tolerance in debates on public affairs}

The task of the $\mathrm{CCH}$ in defining the 'tolerance threshold' is a difficult and thankless one. The Panel must also seek a middle ground that maintains the possibility of protecting the freedom of the democratic public while, in response to the most extreme opinions and false claims, protecting human dignity. ${ }^{12}$ The $\mathrm{CCH}$ undoubtedly searches for a narrow margin in its decisions, where neither the proponents of unrestricted freedom of expression, nor public figures concerned about the quality of public discourse or perceiving their privacy rights as vulnerable are fully satisfied. Perhaps this is exactly what indicates that the Panel is on the right track. The questions of the precise extent to which the enforcement of the rules of the protection of personality recedes in public debates and of the 'threshold of tolerance' of public figures and those involved in public affairs was first sought to be defined in Decision 36/1994. (VI. 24.) AB, ${ }^{13}$ and twenty years later this test was further clarified and amended by Decision 7/2014. (III. 7.) $\mathrm{AB}$, as shown above. Constitutional Court decisions adopted following constitutional complaints lodged against judgments of civil courts follow the standard of this latter decision precisely. Accordingly, calling a media personality a psychopath [3145/2018. (V. 7.) AB], or in a parliamentary debate, accusing the Governor of the MNB of stealing

12 See Juhász, Imre: Fiat libertas, pereat mundus? Alkotmánybírósági Szemle, 2016/1. 88-107.; NAVRATYIL, Zoltán: Az emberi méltóság magánjogi szerepe és a véleménynyilvánítás szabadsága. In: KoltAY-TÖRÖK (2016) op. cit. 121-152.; TÉGLÁSI, András: Véleményszabadság vs. emberi méltóság? Acta Humana, 2015/6. 25-47.; MolNÁR, Hella: A közéleti szereplök személyiségi jogainak védelme. In: Görög, Márta-Menyhárd, Attila-Koltay, András (eds.): A személyiség és védelme. Az Alaptörvény VI. cikkelyének érvényesülése a magyar jogrendszeren belül. Budapest, ELTE ÁJK, 2017. 15-32.

13 It was not really successful, as the case-law has only rarely applied the 1994 CCH standard effectively. SzOMORA, Zsolt: Az alkotmányos követelmények hivatkozási tipológiája becsületsértési és rágalmazási ügyekben hozott büntetöítéletekben. Jogtudományi Közlöny, 2014/10. 469-476. 
[3374/2019. (XII. 19.) AB] does not exceed the tolerance threshold applicable in public affairs disputes [see also even 3308/2020. (VI. 24.) AB].

On decisions of criminal law relevance, the situation has evolved in a similar way. The criminal law counterpart of Decision 7/2014. (III. 7.) AB, that is Decision 13/2014. (IV. 18.) AB, partly confirmed the 1994 criterion set for criminal law, which concerns false allegations: "The freedom of expression relating to public affairs fully protects facts that are proved true, while it protects the act of stating or spreading false facts only if the person spreading the rumour was not aware of the falsehood and did not fail to apply the circumspection required by their profession. These statements of facts, capable of libel, constitute a criminal offence of defamation and hence are punishable" (Paragraph 41). However, in connection with the freedom of expressions and value judgements, it cited Decision 7/2014. (III. 7.) AB:

"The freedom of expression no longer provides protection for self-serving statements which are outside the scope of the debate of public affairs and thus are related to private or family life and aim solely at humiliation or the use of insulting or offensive expressions, or the violation of other rights. [...] Besides, it does not protect an opinion expressed in a public debate if the statements formulated violate the unrestrictable essence of human dignity; as such, they are the embodiment of an obvious and grave defamation of the [subject's] human status." (Paragraph 40)

Constitutional Court decisions made following constitutional complaints lodged against the judgments of criminal courts mostly follow exactly the standard set out in Decisions 13/2014. (IV. 18.) AB and 7/2014. (III. 7.) AB. ${ }^{14}$ Writing about the city's chief notary as 'a lying, vile, unworthy man' who 'violates the law', is a manifestation protected by freedom of expression [3329/2017. (XII. 8.) AB]. A statement about a notary of another city that "there is racism, discrimination, and we, the residents, even have to put on a good face for it. Please strike down this racist body of representatives and notary" and "to me it seems they were tax fraudsters, and the local notary is a part of it", and "she discriminates against and puts people of Roma origin at a disadvantage", and "whoever is a party to a series of wrongdoings should not be a guardian of the law!" are also protected by freedom of expression [3263/2018. (VI. 20.) AB]. ${ }^{15}$

14 For an analysis of 13/2014. (IV. 18.) AB, see Szomora, Zsolt: Az Alkotmánybíróság büntetőítéletet megsemmisítő döntése a közszereplők büntetőjogi becsületvédelméröl. Jogesetek Magyarázata, 2014/3. 13-22.; Szomora (2016) op. cit.

15 After the Kúria upheld the previous final court decisions despite the CCH's decision, after reconsideration of the case, the $\mathrm{CCH}$ commented again, emphasising that, since the communicated opinion did not violate human dignity, the courts could not constitutionally classify it as violating personality rights. See Decision 29/2019. (XI. 4.) AB, paras 39-45. For an analysis of the case, see Botos, Mihály Bálint - GÁL, Andor: Az Alkotmánybíróság határozata a véleményszabadság büntetőjogi korlátját tévesen megállapító bírósági döntések megsemmisítéséről: A valóságbizonyítás formalizált eljárásban történő lefolytatása mint a szólásszabadsághoz való jog érvényesülésének követelménye. Jogesetek Magyarázata, 2020/1-2. $7-14$. 
According to the facts on which Decision 3159/2018. (V. 16.) AB is based, the mayor of a city declared that the applicants from the teaching profession were 'the weakest in professional terms' and they had been dismissed as a result of it. In the review proceedings, the Kúria acquitted the mayor of the charge of defamation. The Constitutional Court of Hungary rejected the complaint lodged against this decision, but in the course of this it did not refer to its 2014 decisions.

However, Decision 8/2018. (VI. 5.) AB found that the title of a newspaper article may be defamatory in itself and therefore if it contains a false statement (in the specific case, the headline was 'The bishop is under investigation on the grounds of coercion'), its protected or unprotected nature under freedom of expression must be assessed separately from the text of the article:

"Due to the genre and its aforementioned role, the title of the article may of course contain simplifications and inaccuracies: the accuracy of the title is limited by both the justified degree of attention and the need to grasp the substance of the content. However, the question of the lawfulness of the resulting simplifications and inaccuracies does not depend on whether they are offset by the other explanatory parts of the article but on whether they may themselves be considered inaccuracies that are not misleading or deceptive as to any important information. Namely, the title of the press article - due to its specific role - cannot in itself contain material, a misleading inaccuracy or untruth in connection with a circumstance that is important for the article as a whole." (Paragraph 32)

Constitutional Court Decision 3263/2018. (VII. 20.) AB interpreted the right to honour in light of the free debate of public affairs, highlighting that the right to honour does not really provide any protection in debates on public affairs and that only statements that go beyond the damage to an individual's honour and which offend the unrestrictable aspect of human dignity may be sanctioned (Paragraphs 40 and 41).

Constitutional Court Decision 3333/2018. (X. 26.) AB provides an example of speech going beyond the limits of freedom of expression, which is considered to be infringing when applying the standards set by the $\mathrm{CCH}$ in 2014. In this case, an opinion about the Deputy Attorney General of the Central Investigation Prosecutor's Office was published on a video-sharing portal claiming that "it is possible that the Zionist dwarf obtained his degree for a gouty Kosher goose in the Tel Aviv wholesale market" (Paragraph 3). Although this statement qualified as an opinion stated in a public affairs debate and the Deputy Attorney General also set a higher tolerance threshold in view of his status, the value judgement against him went beyond the protected limits of freedom of expression (Paragraphs 36-38).

Constitutional Court Decision 3030/2019. (II. 13.) stated that phrases that otherwise qualified as defamatory in the pre-litigation case ('heap of shit' and others, see above) could be re-communicated if they were repeated in the context of reporting on court proceedings which had been initiated because these phrases qualify as public matter, in view of the nature of the dispute. Disclosure in this case is not an end in itself, or 
against the human dignity of the victim, but aims at informing the reader about the incident (Paragraph 40).

Constitutional Court Decision 3322/2019. (XI. 26.) AB was adopted after a representative of one of the county local governments had lodged a complaint because the petitioner had called him 'gay' in a comment on the representative's social media site. According to the CCH's chamber, the classification of this remark was made by the courts, taking constitutional considerations into account. In this context, the $\mathrm{CCH}$ considered the circumstances in which the public actor was affected by public affairs to be important and thus the courts applied the least serious possible sanction (Paragraph 30).

Constitutional Court Decision 3357/2019. (XII. 16.) AB stated, following a newspaper article about the Guardianship Office referring to serious abuses and infringements by the staff of the Guardianship Office, that its content in the case had been properly classified as an allegation of fact and that defamation had been correctly established due to the failure to prove it (Paragraphs 37-39).

As a prelude to Decision 3048/2020. (III. 2.) AB, the petitioner referred to an opinion, disseminated on the victim's community media site on the planning process of the local mortuary, as a 'virus'. This was meant to indicate that the victim had influenced the behaviour of others, including municipal representatives, and as such this speech was not a self-serving insult of that person but a reference to the effect on the community of the victim's conduct, (albeit one which was undoubtedly insulting to his person; Paragraph 30). As a consequence, the decisions of the courts establishing that the defamation had taken place amounted to a violation of freedom of expression.

Constitutional Court Decision 3465/2020. (XII. 22.) AB established that "legal persons may also have a right to have their activities or personalities protected by the State against self-serving defamation" (Paragraph 36). This is indeed the case, despite the fact that human dignity may obviously be associated with a human being. Nevertheless, in the specific case at hand, the opinions expressed against an urban property manager and a limited company engaged in asset management ("the private prosecutor is acting irresponsibly, the city's housing policy is irresponsible, the private prosecutor may be accused of misappropriation and negligence and is also liable for maintaining a risk to life, endangering incapacitated and minor persons"), which were deemed by the courts to be defamation, were considered to be tolerated by the petitioner, so the court decision is incompatible with the protection of freedom of expression (Paragraphs 35-40).

However, Decision 3328/2017. (XII. 8.) AB adopted in the last criminal case discussed, was different in a significant respect from the test for defamation by making false statements, as established in 1994 and confirmed in 2014. The statement of reasons concluded that, since defamation as a criminal offence may only be committed if it was done deliberately, one of the elements of the test established in Decision 36/1994. (VI. 24.) AB may no longer be maintained - the circumstance where the person who "did not know the falsehood (of the statement of fact violating one's honour) because of his failure to pay attention or exercise the caution reasonably expected of him pursuant to the rules applicable to his profession or occupation, taking into account the subject matter, the medium and the addressee of the expression in question". The $\mathrm{CCH}$ attributed 
special significance to the fact that the legislator does not deem defamation caused by negligence to be punishable as a criminal offence in the effective Criminal Code. Based on this and taking the facts in the statement of reasons for Decision 34/2004. (IX. 28.) AB into account, it concluded that "the constitutional expectation concerning defamation caused by negligence can no longer be maintained" (Paragraph 63).

The abovementioned Decision 34/2004. (IX. 28.) AB does indeed contain argumentation along these lines. However, I am of the opinion that neither there, nor in Decision 3328/2017. (XII. 8.) AB is the point of departure appropriate: The decision of 1994 did not intend to introduce defamation caused by negligence, only provided grounds for exemption with respect to the conduct discussed, in order to explore the reality of the given statement. As the 2004 decision rightly concludes: "The criminal act of defamation laid down in Article 179 of the Criminal Code [the former one, adopted in 1978] may exclusively be committed deliberately and, in order to establish the deliberate nature of the act, it is necessary for the perpetrator to be aware of the fact that the statement of fact is capable of offending one's honour." Therefore, the notion of deliberate nature only refers to the publication of offensive statements and does not imply that only deliberate lies may be offensive. The perpetrator needs to be aware of the fact that his statement is capable of negatively impacting the social reputation and perception of the person targeted. Such a negative effect can also be achieved by making true statements, which the court might allow to be proved (Article 229 of the Criminal Code). If a court does not permit the evidence to be given, an otherwise true statement might also be defamatory. It is enough if the person who did not proceed with due care and diligence when establishing the truth of the statement knows that his statement might have negative consequences for the person concerned and thus his conduct will be regarded as deliberate. The crime of defamation may be committed with a potential intention. ${ }^{16}$ As a result, the statement of reasons for Decision 3328/2017. (XII. 8.) $\mathrm{AB}$ errs at this point and it is also questionable whether it will be applied by the $\mathrm{CCH}$ in the future in cases with criminal law relevance. If applied, it may even lead to a narrowing down of the scope of freedom of expression, since the above-cited constitutional requirement set in the 1994 decision did not determine the conditions for establishing liability but rather the grounds for exemption from it. This implies that if compliance with the duty of care cannot in the future justify an exemption from the establishment of defamation, then a deliberate disclosure of untrue facts will suffice in itself.

\subsection{Protection of reputation and honour - rumours}

Under the Civil Code, the Criminal Code and in related case-law, rumour means the transmission of information coming from someone else and is, in principle, subject to the same treatment as untrue and offensive statements of fact coming from the communicator, that is not coming from others. Rumour is among the statutory elements

16 Szomora, Zsolt: Rágalmazás. In: Karsai, Krisztina (ed.): Kommentár a Büntetö törvénykönyvhöz. Budapest, CompLex, 2013. 475. 
of protection of reputation [Civil Code, Article 2:45(2)]; press remedy (Act CIV of 2010 on the Freedom of the Press and the Fundamental Rules of Media Content, Article 12), as well as defamation (Criminal Code, Article 226) - and if committed, in the former two cases, it may be grounds for a civil lawsuit. According to PK Resolution No 14 on the right of reply against the press - adopted under the scope of the 1959 Civil Code, but which also applies accordingly with regard to the application of the Civil Code and Act CXXX of 2016 on the Code of Civil Procedure,

"(t)he remedy of a false statement of facts is necessary even if the communication originates from a third party. For this reason, the law allows for press correction in the event of both making statements based on their own experiences and relaying or communicating, that is disseminating, information received from others. Correction therefore applies to a press publication with false content or which misstates true facts that otherwise accurately communicated the statement of facts or declaration of another person (entity), or takes over the publication of another entity (press organ).” (Article I)

This theorem thus lays down the general rule, the validity of which may be extended to the interpretation of the statutory elements of the protection of reputation. The media have long disputed the compatibility of this rule with the right to freedom of the press. The interest in publishing a report on public affairs and public events may conflict with the interest in the protection of reputation or the publication of true statements. In many cases, the media have no or hardly any time or opportunity to check the truth content of information. The publication of false statements by public figures in itself is also newsworthy, and indeed no report on public affairs is conceivable in the absence of it. Furthermore, on policy questions, it cannot decide in favour of any of the opposing positions and it does not always have the opportunity to listen to the other party either - although a fundamental ethical requirement for the media is to make efforts to do so.

Under the scope of the Fundamental Law, three $\mathrm{CCH}$ decisions have already been adopted on the issue of rumour. The first of these, Decision 34/2017. (XII. 11.) AB upheld that:

"it is a constitutional requirement that the media content provision activities of a media content provider who faithfully reports on statements made on each other in a press briefing of public figures in a debate on public affairs, without its own assessment, clearly identifying the source of the communications and also providing the opportunity to defend himself to the person concerned with statements of fact that may be offensive to his reputation, cannot be considered as a rumour that would provide reason for civil law sanctions for personality right infringement." (Operative Part, Point 1)

According to the $\mathrm{CCH}$, the courts must consider whether the press acted properly in drafting the report and in terms of its content (Paragraph 32). The decision emphasises that the primary task of the press is to disseminate information on public affairs to the 
public, the relevant element of which is the dissemination of the speeches and positions of public figures, although it cannot perform this activity without any restrictions.

One of the basic responsibilities of journalists is to check the credibility of the news and information they publish, but this does not mean that identical criteria should be applied to assess liability for false statements of facts in all cases, with no regard to constitutional considerations. According to the $\mathrm{CCH}$, such a circumstance to be assessed is the interest in the flow of information on public affairs and the relationship of the press to statements made by it; for example, in relation to press conferences by public figures, these aspects should be given particular weight (Paragraph 41). At the same time, the freedom of the press to provide information cannot be unlimited. One of the main tasks of journalists is to verify the truthfulness of the news they intend to publish (Paragraph 42). The media have a responsibility to inform the public about what is said in public debates, but, as it acts as a medium (channel) rather than an independent opinion-maker in such cases, its responsibility for transmitting infringing allegations is limited (Paragraph 46).

The Constitutional Court decision upholds the set of cases specified in the caselaw in which the press may be exempted from liability for infringing allegations made in communications by others. The case-law, which evolved in the context of the concept of civil law rumours, initially considered the communication of official information about criminal proceedings as such, and then the set of cases subject to similar proceedings was gradually extended to cover reports of other court and official proceedings. The decision also considered the coverage of press conferences by public figures to fall under the same assessment as the above set of cases, emphasising that this does not affect the general obligation of the press to verify the truthfulness of the facts it communicates but sets out a case for their exemption from liability arising from it (Paragraph 47).

With regard to the limitation of the exemption from liability, the decision specifies conditions under which the press does not commit any violation of reputation when transmitting the content of press conferences held by public figures. These requirements are as follows: fair communication of what was said at the press conference, identification of the source of the communication (clear indication of it) and refraining from formulating one's own evaluation. In addition to this, in this case, the $\mathrm{CCH}$ considered the publication of the position of the opposing party affected by the related speech connected to the disputed article to be one of the conditions that may be assessed for the purpose of granting exemption from liability. At the same time, the Panel upheld that any deliberate departure from any of the above conditions, which may result in the establishment of liability, is to be assessed as an abuse of the opportunity to prove the truth, which might imply the possibility of establishing liability, but with regard to the specific facts other relevant circumstances may suggest such an abuse (Paragraph 48).

This decision is undoubtedly progressive and is capable of loosening the rigid caselaw in favour of freedom of expression, but it may also be criticised. The constitutional requirement set out in the decision highlights media content providers, hence, with regard to rumours, the exception to the application of the objective form of liability may only be applied to such professionals (the 'press') and as such this approach is over- 
restrictive. Freedom of expression typically protects the content of the communication, irrespective of the person speaking (see, for example, the relevant rules on the protection of personality or sanctioning hate speech), and the Civil Code does not differentiate between speakers either. Therefore, if someone reports responsibly on the press conference of a public figure, he should be granted exemption, regardless of whether he is a media content provider or only an individual speaker (blogger, social media user, etc.). The doctrine of freedom of expression and the Civil Code do not allow these two to be separated with regard to rumour: The press has no obligation to serve the public interest by presenting debates on public affairs, but this service may be performed by other 'non-press' entities.

It is also worth noting that this constitutional requirement is also restrictive in that it extends the scope of this exemption only to reports on press conferences held by public figures. While a press conference is an important and common means to obtain information, it is by no means the only method. In fact, reporting on positions published on public affairs is important to the press and its audience in general, irrespective of the means of communication. As case-law develops further, it will be justified to consider the possibility of the press (or any speaker, as mentioned above) enjoying a general exemption from liability for rumour, as long as they make an accurate and detailed presentation of public statements, granting the other party an opportunity to speak and identifying the informant.

The second decision on the subject of rumour, Decision 3002/2018. (I. 10.) AB, was adopted one month after the first one, and it immediately narrowed the scope of application of the constitutional requirement referred to therein, without setting a new constitutional requirement. In that case, the media published an article on a matter of public interest (racist manifestations by football fans, in front of a school in the town of Konyár), which also included an Internet link. Through this link, a recording could be accessed in which the chairman of the local Roma municipality, the first defendant in the lawsuit, associated this act with the right-wing political party Jobbik ('Jobbik came in, came in on a bus'). The majority opinion concluded that the media should only be exempted from liability for a rumoured statement of fact, made indirectly accessible as linked content in this specific case, if the media content in question contained only the statements of persons involved in the public discourse and nothing else beyond it.

"In the interpretation of the Constitutional Court - taking the constitutional requirement established in 34/2017. (XII. 11.) AB into account - press coverage is outside the scope of interpretation of dissemination if the media content focuses only on the up-to-date and credible statements of the persons participating in the debate on the public affair. In the given case, the press coverage did not focus on the statement of the first defendant, but the description of information related to the events, which is contradictory. Consequently, in the case at hand, the press coverage examined qualifies as rumour." (Paragraph 77)

The media content underlying the judgment which was challenged with the constitutional complaint, as was also pointed out by the Kúria in its judgment, qualifies 
as fact-finding writing, an investigative article, and consequently "the presentation of contradictory information related to those events". However, in my view, the majority statement of reasons refers to the constitutional requirement contained in Decision 34/2017. (XII. 11.) AB in such a way that it actually departs from it. The 2017 decision excludes from the general rule applicable to rumour those reports that "faithfully report statements made in the public affairs debate at a press conference by public actors, without any evaluation of its own, clearly indicate the source of the communications and ensure the opportunity for rebuttal by the person affected by the allegations that may damage his reputation." It does not follow that, as would be expected from Decision 3002/2018. (I. 10.) AB, media content should not seek to "present conflicting information related to events".

I would venture that the prohibition of making one's own evaluation set out in Decision 34/2017. (XII. 11.) AB does not apply to the entire media content that contains the report but specifically to the part mediating what was said at the press conference. I believe that it is not realistic for the media to be expected to report what is said by a public figure exclusively, without adding any text associated with it. If nothing else, a title, a lead and captions need to be attached to the report, which in themselves require a creative contribution to what has been said on the part of the media. If the media assume the informative role defined by the $\mathrm{CCH}$ as their constitutional mission, and thus their task is to present and explore the truth and to actively seek it, rather than being a mere communication surface, obliged to passively reflect its own content, then, after presenting opposing views, they must take a stand on the issue of truth and falsehood. However, even if this is so, they must act responsibly and channel the communications of others accurately, in which case they are exempted from liability for rumours. In my view, the constitutional requirement in Decision 34/2017. (XII. 11.) AB envisages this not in a general sense but specifically with regard to official press conferences.

Apart from this, the argumentation in Decision 3002/2018. (I. 10.) AB clearly contradicts the earlier decision at a certain point. It mentions the presentation of 'contradictory information' as an argument against exemption, while the earlier decision makes addressing opposing interested parties or offering them the opportunity to speak a condition for determining whether the press may be held liable. It is clear that if a piece of media content consists solely of communication by one interested party, then the media has fulfilled its democratic role only partially. At the same time, Decision 3002/2018. (I. 10.) AB does not restrict the theoretical possibility of exemption from liability to the communication of what was said at a press conference, so in principle it can extend to any public affairs, albeit only with the above restrictions (that is without any contradictory information and the media's own position).

The judgment in Magyar Jeti Zrt. v. Hungary ${ }^{17}$ was adopted in the wake of the case covered by this $\mathrm{CCH}$ decision. The applicant made a complaint before the ECtHR, claiming that the Hungarian authorities had violated his right to the freedom of expression. The case is particularly interesting in that the dissemination was committed by embedding an Internet link in the article; as such, the case also concerned the

17 Magyar Jeti Zrt. v. Hungary, no 11257/16, judgment of 4 December 2018. 
legal judgment of a new form of communication made possible by Internet-based communication: Is it possible for the simple publication of a link to be infringing, if this leads users to a text or video containing an infringing, untrue statement? According to the judgment of the ECtHR, if the journalist and/or the media content created by him did not express his agreement with the infringing content and if he proceeded in good faith and with due diligence, respecting the ethical rules of journalism or professional ethics, then posting the link in itself does not amount to defamation. In addition, the context of the infringing content needs to be considered, namely what was the legal case in which it was posted for public consumption and who it affected. The threshold of tolerance of outstanding public figures (in this case a parliamentary party) in such cases must be higher than usual (Paragraphs 77-82). Therefore, accoridng to the ECtHR, Hungary violated the applicant's right to freedom of expression.

In a subsequent decision concerning the issue of rumour, the $\mathrm{CCH}$ rejected a constitutional complaint seeking the establishment of the unconstitutionality of the Kúria's judgment and its annulment in Decision 3217/2020. (VI. 19.) AB, concluding that the Kúria had correctly applied the constitutional requirements set out in Decision 34/2017. (XII. 11.) AB. Decision 3466/2020. (XII. 22.) AB also rejected the complaint, arriving at the same conclusion. The article challenged in this case reported on a press conference by a politician without providing an opportunity to communicate the response of the other party named there, that is the petitioner. According to the $\mathrm{CCH}$, this remained within the scope of lawfulness, since the allegations made in connection with the petitioner at the press conference had already come to light earlier and the petitioner had had the opportunity to react to them (Paragraph 51).

\subsection{Protection of reputation and honour - online comments}

Questions related to comments on individual online content (with or without content provider moderation, related to comments on an article or post published by a 'reader', that is the user on an Internet interface) were not new at the time when the $\mathrm{CCH}$ adopted its one and only comment decision to date. The main issue in the debate is whether Act CVIII of 2001 on certain aspects of electronic commerce services and information society services (hereinafter referred to as the e-Commerce Act) or the general rules of civil law apply to the liability of platforms that provide the opportunity to comment, that is whether, upon learning of a personality right-infringing comment, prompt removal by the platform leads to exemption or, if it is involved in the publication of the infringing content, the fact of infringement leads to the establishment of liability.

Under the e-Commerce Act, although the hosting provider is, in principle, liable for the infringing information, it is not required, on the one hand, to verify the information which it merely transmits, stores or makes available, and, on the other, it is exempted from liability if certain conditions are satisfied. The hosting provider shall be released from liability if it was unaware of the infringing nature of the content and took action without delay to make such content inaccessible as soon as the provider became aware of it. (The content service providing an opportunity to comment may be considered as a hosting service according to the conceptual system of the e-Commerce Act.) In contrast, according to the relevant provisions of both the Civil Code of 1959 and the 
currently effective Civil Code, the fact of the publication of content that infringes a personal right is the one and only decisive factor, and even immediate removal of content upon being informed of its infringing nature does not result in exemption of the host from the objective legal consequences.

The only decision of the $\mathrm{CCH}$ related to online comments so far, that is Decision 19/2014. (V. 30.) AB, triggered considerable criticism. ${ }^{18}$ In the case at hand, the fact of infringement was not disputed between the parties, nor was it disputed by the website operator (hence the $\mathrm{CCH}$ did not conduct a substantive investigation in this respect), but it merely objected to the fact that it would be subject to any liability for 'alien' content, regardless of whether the entry had been taken down (removed) without delay upon notification of its infringing nature, relying on the e-Commerce Act in his arguments (Paragraph 56). According to the decision, the liability of the website operator is based solely on the fact of the infringement; other circumstances cannot be decisive. In the event of an infringement, no distinction can be made between different websites and the operator's legal liability (Paragraph 64).

The statement of reasons attached to the decision is contradictory in many respects and, unfortunately, fails to provide a general approach which would be applicable to the constitutional characteristics of the online public sphere, which functions according to a different logic from legacy media, but which is increasingly important for the discussion of public affairs. ${ }^{19}$ Nevertheless, it should be noted that, as far as liability for the infringing comments is concerned (which was the most crucial issue addressed by the decision), the approach applied by the $\mathrm{CCH}$ is not without precedent: It was in harmony with the Hungarian jurisprudence prevailing at that given point in time. What is more, the ECtHR did not subsequently find it (namely the application of general civil law liability rules on the grounds of violation of personality rights) incompatible with Article 10 of the European Convention on Human Rights, either. This is how the ECtHR decided prior to the $\mathrm{CCH}$ decision in Delfiv. Estonia ${ }^{20}$ and also later in MTE and Index v. Hungary, filed to the ECtHR as a follow-up case based on the case underlying the $\mathrm{CCH} .{ }^{21}$ The reason for Hungary's condemnation in this latter case was not the application of civil liability per se but a different assessment of the content of the comments, which - according to the ECtHR - could not have been considered to be

18 See, for instance, BALOGH, Éva: Egy lépést hátra. A magyar Alkotmánybíróság döntése az internetes hozzászólásokért való felelősségről. Pro Futuro, 2015/1. 142-150.; GRAD-GYENGE, Anikó: Commentare necesse est - néhány gondolat az Alkotmánybíróság „komment-határozatáról”. Glossa Iuridica, 2015/2. 122-142.; KLEIN, Tamás: A tárhelyszolgáltató „omnipotens” felelőssége mint alkotmányjogi problematika: A harmadik személy tartalmáért való szolgáltatói felelősség az interneten. In: KoLTAY -TöRöK (2016) op. cit. 349-374.; Koltay, András: Az Alkotmánybíróság határozata az internetes kommentek polgári jogi megítéléséröl. Jogesetek Magyarázata, 2015/1. 9-21.

19 For a more detailed and informal explanation of the statement of reasons, see the text written by the Judge-Rapporteur in the case, Bragyova, András: Szólásszabadság és sajtószabadság az internetes kommentek példáján. In: FeJes, Zsuzsanna - TöröK, Bernát (eds): Suum cuique: ünnepi tanulmányok Paczolay Péter 60. születésnapja tiszteletére. Szeged, Pólay Elemér Alapítvány, 2016. 473-490. 
infringing. The approach taken by the $\mathrm{CCH}$ on the main issue was therefore compatible with Strasbourg's case-law on Article 10 of the Convention. Thus, neither the fierce criticisms of the CCH's decision on the main issue nor the 'victory processions' following Hungary's condemnation by the ECtHR may be considered to be wellfounded, even if the statement of reasons in the $\mathrm{CCH}$ decision is indeed confusingly inaccurate or contradictory in several respects. ${ }^{22}$

\subsection{Protection of image rights}

Article 2:48 of the Civil Code states that “(1) Recording a person's image or voice and using such a recording shall require the consent of the person concerned. (2) The consent of the person concerned shall not be required for recording his image or voice and for the use of such a recording if the recording was made of a crowd or of an appearance in public life." The text seems to suggest that it is not the identification of public affairs but public figures, more precisely those acting in public life, that is the only important consideration, and outside the context of a public appearance it is not possible to reduce the protection of the personality rights and that the application of Article 2:44 might be of some assistance. In contrast, the conclusion reached in the Constitutional Court case-law in the 'images of policemen' cases, by disregarding Article 2:44, was that the freedom of expression and the right to information also provide guidance in the constitutional interpretation of Article $2: 48 .{ }^{23}$

The press often publishes still and moving images in which law enforcement officers may be seen with uncovered faces, and can be recognised. These recordings and photographs typically accompany reports on matters of public interest, so the image of the policemen in itself is not newsworthy. At the same time, the individuals concerned may consider the publication of these recordings as a violation of their right to their images and privacy, emphasising that their recognisable representation does not add any useful information to the reports that is showing their recognisable faces does not 'add' anything to the merit of the public affairs report's content they illustrate.

For the first time, Decision 28/2014. (IX. 29.) AB dealt with striking a balance between the conflicting rights to one's image and freedom of expression in the context of recordings made of the police. In the specific case at hand, an Internet news portal published an article entitled 'Demonstration of a law enforcement trade union' with an associated 'image gallery'. In two images in this collection, two policemen could be seen in a uniquely identifiable manner, in group photographs which also depicted others. The police officers were performing their duty, policing the demonstration, and stood passively in the picture; their behaviour in itself was not or could not be regarded

22 For sober assessments analysing the MTE decision, see SEPSI, Tibor: No comment? Az internetes hozzászólásokért való jogi felelősség. Fundamentum, 2015/4. 106-110.; SzIGETi, Tamás - Simon, Éva: A hozzászólás szabadsága: a közvetítő szolgáltatói felelősség aktuális kérdéseiről. Fundamentum, 2016/2-4. 113-124.

23 For a comprehensive presentation of the case-law related to the right to image, see BoronKAY, Miklós: A képmáshoz és a hangfelvételhez füződő jog. In: CseHI Zoltán - Koltay, András - NAvratyiL, Zoltán (eds): A személyiség és a média a polgári és a büntetőjogban. Budapest, Wolters Kluwer, 2014. 11-56. 
by the press as extraordinary for any reason. These images did not add any additional information to the coverage, nor did they depict the police officers concerned in an offensive, hurtful, demeaning or distorted way.

It is important to note that the $\mathrm{CCH}$ did not attempt to force the facts of the case into any of the exemptions provided for in the Civil Code. The challenged images were not made of a crowd, and the $\mathrm{CCH}$ avoided classifying the work performed and the service provided by the police in public areas as public speech, since it cannot be considered as such. Earlier, the Hungarian Supreme Court had argued, citing the lack of public figure status, in favour of the protection of images of police officers since, as a general rule, a police officer is not a public figure, despite exercising state powers, and his work in public does not constitute public speech. ${ }^{24}$

Nevertheless, coverage of a police officer's or other law enforcement personnel's activities by the media conceptually affects public affairs, precisely because of the transparency and criticism of the exercise of state powers, therefore it is not sufficient simply to prove that they are not public figures. ${ }^{25}$ The Constitutional Court of Hungary upheld with general validity (that is to say, not only for law enforcement officers but also for those not exercising state powers), that their image can be freely published if "[t]he non-offensive footage taken in a public place, depicting the person concerned objectively, may normally be made public without authorisation if it relates to a report of public interest and is linked to free information on contemporary events" (Paragraph 44). This is how images of police action should also be assessed (Paragraph 43). The Kúria finally accepted this approach, ruling that if "the person exercising state powers acts in the course of events influencing the public sphere, the exercise of his personality rights relating to his image and their restrictability might be subjected to rules that are different from those pertaining to the general protection of the personality rights of private persons solely participating in public events." ${ }^{26}$

Therefore, following this $\mathrm{CCH}$ decision, constitutional aspects related to free reporting, access to information, that is freedom of expression and the press should also be included in the interpretation of the Civil Code. For some time, the $\mathrm{CCH}$ and the Kúria have not considered this aspect uniformly in individual cases, as evidenced by recent $\mathrm{CCH}$ decisions adopted in response to constitutional complaints, which have reaffirmed the importance of considering the public interest aspect [see 16/2016. (X. 20.) AB and 17/2016. (X. 20.) AB].

As the Kúria also declared the communication of the images unlawful in a new judgment following the decision by the $\mathrm{CCH}$, the case was again brought before the $\mathrm{CCH}$. The Kúria assumed that the disclosure of an image of police officers standing

24 For an argument against the public figure status of police officers, see Pokrócos, György: A rendőr képmásának nyilvánosságra hozatala. Belügyi Szemle, 2019/2. 89-108.

25 Regarding the constitutional issues inherent in the issue, see BALOGH, Adrienn-HegYI, Szabolcs: A Kúria jogegységi határozata a közhatalmat gyakorlókról készült képmás és hangfelvétel nyilvánosságáról. Közszereplö-e a nyilvános helyen szolgálatot teljesítő rendőr? Jogesetek Magyarázata, 2014/2. 29-35.; Somody, Bernadette: A rendőrarcképmás-ügy mint az alapjogi ítélkezés próbája. Fundamentum, 2016/1. $103-112$.

26 BKMPJE decision no $1 / 2015$, para IV(3). 
passively did not carry any additional information, so, in accordance with the deliberation prescribed by the $\mathrm{CCH}$, the Court rightly concluded that the disclosure of the images was not necessary for the purposes of providing adequate information, and therefore it was unlawful. This is a misinterpretation of the decision made by the $\mathrm{CCH}$, however, as made clear in Decision 3/2017. (II. 25.) AB. The starting point is not that an individual's right to image is supressed only when communicating additional information, relevant to the information activity; on the contrary, such a right can only be enforced if the communication is abusive, self-serving, and distorted. Therefore, the presumption is that the disclosure of police images in connection with reporting on a public event is permitted.

"In the event of such circumstances, the courts may examine, in the case of a press body falling within the scope of the Press Freedom Act and the Media Services Act, the fairness and good faith of the coverage as a whole, during which the parties must be granted the opportunity to make such statements, to substantiate and refute them by evidence. However, if such a circumstance did not arise, as it did not in the case at hand, since the plaintiffs did not state that the coverage had represented their presence and role in the event covered by the report falsely (unfairly), and therefore as an end in itself, the courts are required to enforce the primacy of the constitutional interest in the presentation of contemporary events, in line with the interpretation range set out in 28/2014. (IX. 29.) AB.” [3/2017. (II. 25.) AB, Paragraph 25] $]^{27}$

Representatives of other professions may also be photographed at a public event against their will. Constitutional Court Decision 3021/2018. (I. 26.) AB concerned the right to image of legal representatives acting at a trial, who are legal counsels representing the police in litigation. At the hearing, the legal counsels did not consent to photos being taken of them; the court subsequently ruled that a recording of the images and sound could only be made of the plaintiff's side and of the court itself. However, one of the petitioners in the decision made recordings in which the solicitors were individually identifiable. A printed version of the judgment, which also included the names of the legal representatives, was presented in a recording published later, accompanied by the following commentary: "What is shocking, indeed, is the way in which the [Sándor] Pintér (the home secretary of the Hungarian Government) Police are being defended in a sly, and let's say unprincipled way by their legal counsels."

27 For a comprehensive overview of police image cases and the issues raised by them, see Erik FEJES: A rendvédelmi testületek hivatásos állományába tartozó személyek képmáshoz füződő jogának korlátozhatósága. In: GöröG-MenYhárd-Koltay op. cit. 143-161; PAPP, János T.: Az Alkotmánybíróság két újabb határozata a rendvédelmi dolgozók képmásának nyilvánosságáról. Jogesetek Magyarázata, 2016/4. 5-11.; PAPP, János T.: A rendőrök képmáshoz való jogának kérdése. In: GöröG-MenYháRD-Koltay op. cit. 119-142.; SÁndor, István: A képmáshoz való jog és a sérelemdíj bírósági gyakorlatának tendenciái. Belügyi Szemle, 2020/4. 53-69.; TóTH, J. Zoltán: Rendőrképmás: sajtószabadság és képmáshoz való jog a polgári jogi és az alapjogi jogosultságok keresztútján. Pro Futuro, 2017/2. 110-128. 
The Constitutional Court of Hungary saw no reason to annul the Kúria's decision, which classified both the preparation and publication of the recording as infringing. An important consideration was that the recordings were made at a court hearing, the disclosure of which is subject to special rules, and that, on the basis of these rules, the acting judge lawfully prohibited the recording from being made, in an order (Paragraph 24). Both the context and the role of the affected individuals differentiates this case from police image cases; "the recording and disclosure of images, despite the prohibition of a court order, (and) in the absence of a manifest unfoundedness of the judicial discretion, cannot be considered a proper, non-abusive exercise of press freedom" (Paragraph 30).

The petitioner in Decision 23/2019 (VI. 18.) AB was a television service provider that reported in its news broadcast on a trial pending before the Kúria, in which it did not disguise the face of the law enforcement worker accompanying the accused, and presented him in a recognisable way. In this case, the $\mathrm{CCH}$ had to rule on an important point, different from the facts of the case in the previous policemen image cases: Can the image of a person exercising state power, present at a court hearing, that is not in a public place, be disclosed as part of the press coverage of the trial (Paragraphs 29 and 30)? The Panel established that the court decisions in the case at hand were based on the protection of the right to image, but, at the same time, did not record any element of the coverage that would have violated the dignity of the person concerned. However,

"the pictorial representation of the activity of a person exercising state power in this capacity is hampered only if there is a special constitutional reason for it. The administration of justice and the independence of the judiciary may justify a restriction on freedom of the press in the courtroom, but becoming recognisable is not such a reason in itself. No person exercising state powers in accordance with the conclusions drawn in 28/2014. (IX. 29.) AB may cite the protection of human dignity as grounds at a court hearing because he becomes recognisable in media content." (Paragraph 41)

The Constitutional Court of Hungary case-law also extends to constitutional issues related to the disclosure of the images of public and political figures. Based on Decision 3313/2017. (XI. 30.) AB, an image taken of a political figure present in a courtroom as the accused person, even if he was acquitted in subsequent proceedings, is likely to be of great interest to the public and this is linked to the status of the accused as a public figure. The media may objectively report - including by visual means - on the state of play of criminal proceedings, providing the news coverage accurately reflects the current state of play of the given proceedings and respects the assumption of innocence as a fundamental constitutional principle. Visual representation in itself does not violate this principle, nor does the presentation of physical means of coercion (handcuffs) used on the accused necessarily constitute abusive or degrading treatment (Paragraphs 5162). The motion alleging a violation of personality rights was accordingly turned down by the $\mathrm{CCH}$.

Constitutional Court Decision 3348/2018. (XI. 12.) AB was initiated following the disclosure of another accused political public figure. As an illustration for an article on an internet news portal, the petitioner used an image of the person previously taken 
for another news portal during a criminal prosecution. An important circumstance is that, following the publication of the image, the public figure concerned had previously won a civil lawsuit against the news portal that took the image, successfully relying on the abuse of his image. However, in this case, the $\mathrm{CCH}$ stated that, nevertheless, the constitutionality of the use of the image in the specific case may be examined separately (Paragraph 36). The image is closely related to the content of the newer article and the court proceedings of public interest presented in it, which were related to the public figure quality and position of the former politician. Furthermore, the image does not depict him in a humiliating situation, in a way that would seriously hurt or violate the unrestrictable essence of human dignity that determines human status (Paragraph 37). Accordingly, the publication of the image does not constitute an abuse of the right to freedom of the press (Paragraph 38).

As a prelude to Decision 26/2019. (VI. 23.) AB, footage of a political adviser, who mostly avoids publicity, was taken on a holiday he took abroad, as mandated by the nightclub he visited. An important circumstance is that, in accordance with the general terms and conditions of the establishment, the consultant consented to the production of a recording including his person for advertising purposes, which the nightclub may then use in the course of its own activities. These recordings were republished by a Hungarian Internet news portal. The Constitutional Court of Hungary rejected the constitutional complaint because the report on the consultant's holiday was a public matter, and as such if "the press publishes an image in a matter related to public discourse, the 'protection of image' may only be a genuine restriction on press freedom if the publication of the image violates a fundamental right beyond becoming recognisable (in particular a violation of human dignity or the right to privacy)" (Paragraph 40). The article and its pictorial illustration were not defamatory or insulting, and

"the press shared media content about the privacy of an individual who has an impact on public life in connection with debating public affairs. Since, in this case, the subject of the democratic debate was privacy itself (and the financial situation and lifestyle of the person concerned), and the petitioner consented to recording and sharing it (the image) for promotional purposes, the court correctly interpreted that sharing this information with the general public does not mean the violation of human dignity or the right to privacy." (Paragraph 42)

One of the petitioners in Decision 3467/2020. (XII. 22.) AB was a politician and the other one was his spouse, who is not a public figure. The court decision they challenged rejected their claim for the protection of their right to their images. According to the facts of the case, an Internet news portal posted photos of the politician as well as a profile picture attached to his social media account, depicting him and his spouse. The Panel established that none of the images of the politician could be considered to be depictions of a private event (Paragraph 69). Although the politician's wife could justifiably allege a violation of her rights to privacy in the event of publishing her image, in the specific case at hand she was not recognisable in the profile picture, due to its small size and impossibility of magnifying it, so her fundamental rights were not violated (Paragraph 72). 
Constitutional Court Decision 3019/2021. (I. 28.) AB was adopted after an Internet portal published an article analysing the relationship of a family to the mayor of a county-level town, as well as the evolution of the family members' financial situation, and images of the mayor and family members, originating from other media providers (Paragraph 2). The courts found a violation of the right to image. An important criterion in the $\mathrm{CCH}$ decision was that the published photographs were not shot to illustrate the article but on the occasion of an earlier public appearance. However, the content of the article concerned public affairs (Paragraph 36). After due consideration, the $\mathrm{CCH}$ accepted the constitutionality of the decision delivered by the courts, which "in cases where the image is not related to the public speech to which the communication relates, makes the disclosure of the image conditional on the consent of the person concerned who does not exercise state powers" (Paragraph 38). The CCH turned down the application for annulment.

\subsection{Protection of privacy and personal data in the Civil Code}

The protection of privacy has been named as a personality right in the Civil Code [Article 2:43(b)], the stand-alone content of which is shaped by the case-law. The scope of this personality right must also be determined considering the interests in an open debate on public matters, as must the right to the protection of personal data, which necessarily overlaps with the general right to privacy. ${ }^{28}$

In connection with the scandal surrounding the Quaestor Group (a private corporate group), one individual was involved in seven separate $\mathrm{CCH}$ decisions as petitioner [3209/2020. (VI. 19.) AB; 3210/2020. (VI. 19.) AB; 3211/2020. (VI. 19.) AB; 3212/2020 (VI. 19.) AB; 3213/2020. (VI. 19.) AB; 3214/2020. (VI. 19.) AB; 3215/2020. (VI. 19.) $\mathrm{AB}$. The publishers of newspapers, television media service providers and Internet news portals who had previously been sued published articles about the Quaestor Group scandal, in which they disclosed the name, previous job, the fact of cohabitation and the name of his partner and the family relations of his partner, as well as information on his wider family through this cohabitation, without the consent of the petitioner (who worked for Quaestor Group, and his partner was the daughter of the Attorney General). The articles inferred from this information that the alleged delay in the prosecutor's action in the case may have been related to work and family connections. The articles did not attempt to prove the truthfulness of this line of thinking, however. In earlier decisions, the Kúria upheld previous court judgments that dismissed in their entirety a claim for establishing a violation of personality rights related to privacy and the protection of personal data. Of these seven decisions, there is one exception in this respect, in which the $\mathrm{CCH}$ turned down the complaint, since the courts of first and second instance had established the violation of the right to privacy and personal

28 On the interpretation and possible content of the 'right to privacy' as a personality right see Attila Menyhárd: A magánélethez való jog a szólás- és médiaszabadság tükrében. In: CseHI-KoltAYNAVRATYIL op. cit. 177-226.; GöröG, Márta: A magánélethez való jog mint a személyiségi jog újabb, magánjogi kódexben nevesített vonatkozása. In: BALOGH, E. op. cit. 51-63. 
data protection, which was also upheld by the Kúria [3214/2020. (VI. 19.) AB]. As a prelude to this latter decision, the courts found the disclosure of the petitioner's name unlawful and found that the disclosure of the fact of his partnership and the partner's family relations did not infringe the applicant's right to privacy, and the $\mathrm{CCH}$ shared this opinion.

The Constitutional Court of Hungary stated in all these decisions that involvement in public affairs, also in view of the importance of the public matter, may necessitate the restriction of the right of a petitioner who is not a public figure to the protection of his personal data [3209/2020. (VI. 19.) AB, Paragraph 48 - for simplicity's sake, I will refer below to the first decision only, but the reasoning was essentially identical in all of them].

Regarding the publication of the name, the relevant information could have been provided by reporting without mentioning any name (that is in anonymous manner), so the conduct of the press violated the privacy of the petitioner under Decision 3209/2020. (VI. 19.) AB (Paragraphs 51 and 52). The disclosure of his previous job without his consent was not considered a violation [3209/2020. (VI. 19.) AB, Paragraph 54]. The work relationship with the head of the Quaestor Group, as well as the petitioner's private relationship with the Attorney General, qualify as "personal data relating to a matter of public interest, the disclosure of which cannot be considered arbitrary or unreasonable disclosure; it enjoys a higher level of protection of freedom of expression" [3209/2020. (VI. 19.) AB, Paragraph 57]. With regard to the report mentioning the family relations, the $\mathrm{CCH}$ also attributed more weight to the task of informing the press on the protection of privacy [3209/2020. (VI. 19.) AB, Paragraph 60].

The petitioner of Decision 3308/2020. (VI. 24.) AB was the secretary general of a childrens' holiday foundation, about whom an article was published, including an image and video of the luxury villa he rented, its garden and a car with a covered license plate, as an illustration. The $\mathrm{CCH}$ stated that "freedom of the press does not afford general permission to photograph the property of others" (Paragraph 34). The rights related to the private home are constitutionally protected, according to Article VI(1) of the Fundamental Law. However, this provision does not protect the property itself but instead the privacy of the individual (Paragraph 36). Even so, the published images did not depict anything that could be linked to privacy, and the owner of the rented property had previously made available the address of the property and the pictures taken of it. "The petitioner chose the holiday home as a temporary location for his private life in the knowledge that there are available recordings of it. He may not rely on the violation of privacy due to the re-publication of similar recordings" (Paragraph 36).

\section{Political speech}

In this review, I consider speech to be 'political' when only politicians or political parties can express their views due to a particular situation, which may infringe the rights of others, especially other politicians; these comprise statements made during election campaigns, political advertisements in the media and speeches by members of parliament in plenary or committee sessions of the Parliament. 


\subsection{Freedom of expression during the election campaign}

Thanks to the possibility of the constitutional complaint being made, $\mathrm{CCH}$ case-law could also develop in connection with speeches during election campaigns. A media service provider refused to broadcast the political promotion film of the applicant in the case on which Decision 3122/2014. (IV. 24.) AB is based. The film "depicts a man disguised as monkey, dressed up in a military uniform, who is lip-synching to the voices of former Hungarian prime ministers" (Paragraph 2). According to the position taken by the Kúria, "identifying somebody with an animal at any time qualifies as dehumanising the person concerned, and this, in a given case, may be capable of violating human dignity" (Paragraph 3). The $\mathrm{CCH}$, in agreement with the Kúria, explained that

"the scope of the freedom of expression protected by the Fundamental Law is broader with regard to opinions concerning exercising state powers and politicians acting in public, but even in their case, human dignity has an essential, untouchable core, which persons formulating potential criticism are also obliged to respect. In this election-related case, the depiction of those concerned as animals violates this essential content in a disparaging manner and thereby violates Articles II and IX(4) of the Fundamental Law." (Paragraph 17)

In my view, it is debatable whether the depiction in this case violated human dignity. The decisions adopted by the Kúria and the $\mathrm{CCH}$ do not address the issue of the extent to which satire and parody enjoy the protection of freedom of expression. The conclusion that the phenomenon of public figures metaphorically 'dressing up as animals' may be interpreted as 'identification with an animal', the assessment of which concerns the very essence of the case, is dubious and thus a more detailed elaboration would have been justified. In the period of election campaigns, public figures need to tolerate harsh, sometimes extreme criticism. It is common sense that nobody would think that the filmmakers do not consider the public figures concerned in this case as homo sapiens, and so the film, although it did depict public figures as animals, could not, due to its characteristics as a parody have met the condition of "the total, obvious and severely disparaging negation of the human status of the person concerned" (Paragraph 62).

An important aid in distinguishing between factual statements and opinion statements is the case-law and Constitutional Court case-law which has developed in connection with such statements published during election campaigns, which, moreover, is bound up with the evolving constitutional interpretation of the Civil Code. In Decision 31/2014. (X. 9.) $\mathrm{AB}$, the $\mathrm{CCH}$ used its own case-law as a basis for determining the degree of protection of personality rights afforded to public figures pointing out that: "In an election campaign, the freedom of expression and its restrictions typically need to be interpreted and judged in the personal relationship of public figures" (Paragraph 28). This approach is questionable: Article 2(1)(e) of Act XXXVI of 2013 on the Election Procedures prescribes that rights be exercised "in good faith in accordance with their purpose", that is in the cases discussed, this should be examined (when is it possible 
to make an untrue statement in good faith, whether it is possible in theory to publish extreme and offensive opinions in good faith, and what are the limits of the purposeful exercise of rights during an election campaign period).

The standards established in connection with the protection of the rights of the individual are related to the application of other facts, so it is not self-evident that they may also be relevant in the context of the Electoral Procedures Act. Nevertheless, it is not surprising that both the Kúria and the $\mathrm{CCH}$ drew upon these standards, given the civil analogies in the statement of facts; for example, those related to public figures being affected, the necessary distinction between statements of fact and opinion and the debate or discussion of public affairs. In the specific case, the $\mathrm{CCH}$ essentially overruled the court of appeal:

"The judicial decision did not take into account that the complainant made a statement expressing his opinion. The distinction between a value judgement and the statement of fact may also have constitutional relevance. [...] Therefore, the freedom of expression is given increased protection in relation to value judgements, which surface in a collision between opinions on public affairs, even if they are perhaps exaggerated and heightened." [31/2014. (X. 9.) AB, Paragraphs 29 and 30]

The Constitutional Court of Hungary could have taken the opportunity to define the constitutional framework for the demarcation of factual statements and opinions in its decision. Moreover, the range of choices is not limited to facts and opinions; a more differentiated approach is therefore necessary and different types of statements of fact need to be distinguished from one another (they may be true or untrue) while opinions may have a factual basis that can be examined (this factual basis may be true or untrue), as well as fully subjective opinions and value judgements that have no factual basis.

The petitioner in Decision 5/2015. (II. 25.) AB called himself, at a demonstration on Kossuth Square in Budapest, the only left-wing candidate in a parliamentary byelection. His exact words were as follows: "Fidesz [the government party] has 11 candidates wearing 11 different shirts. The Fidesz team has fake candidates, dividing voters for the opposition, and adventurers who are in preparation. [...] On 22 February, I will defeat the Fidesz candidates in Veszprém." The constitutional background of the decision was again Decisions 36/1994. (VI. 24.) AB and 7/2014. (III. 7.) AB, relating to the protection of the reputation and honour of public figures. Again, in its classification of the statements as facts or opinion, the $\mathrm{CCH}$ came to a different conclusion than the Court: "The decision taken by the judge in the current case grasped the direct content of the statement and stuck to it, neglecting the fact that the complainant expressed his ideas as his opinion" (Paragraph 27). The CCH rightly concluded that the statement in question was an opinion and that what was described should not be interpreted on the basis of its literal meaning: It is obvious that a party cannot nominate eleven different - competing - candidates in the same constituency. However, the $\mathrm{CCH}$ decision once again did not determine the criteria for demarcating statements of fact and opinions.

A nominating organisation in another case shared a video on its social media site, claiming that one of the rival candidates running in the by-election for the Parliament, 
who was a member of the supervisory board of MAL Zrt at the time when the 'red sludge disaster' (an industrial accident at a caustic waste reservoir chain) occurred in 2010, might be liable for the disaster. According to the video, "PF was sitting among the management of the company"; furthermore, "PF would have had the responsibility to prevent the disaster, but he did not do anything" [9/2015. (IV. 23.) AB, Paragraph 3]. The Kúria deemed these words as a misrepresentation of the facts and argued in detail, with legal references, that a member of the supervisory board may not be considered to be the 'manager' of the given company. The Constitutional Court of Hungary rejected this in its decision, classifying the statement expressed in the video as an opinion (Paragraph 43).

The criticism made in Decision 5/2015. (II. 25.) AB is also valid here. The constitutional aspects of the demarcation of facts and opinions are not identified in this decision, nor is it fully clear why the $\mathrm{CCH}$ considers (in my view erroneously) the examined statement to be an opinion. Undoubtedly, in certain cases differentiating between statements of fact and opinion is difficult and presupposes a necessarily subjective decision, but the $\mathrm{CCH}$, in its decision, should have provided an explanation of why it provided an interpretation that is different from that of the Court; all the more so because, in this decision, the Kúria made genuine efforts to provide reasons for interpreting the claims as a statement of facts.

Constitutional Court Decision 3107/2018. (IV. 9.) AB was handed down in respect of a leaflet featuring the following claim: "TB, your MP, has uttered the name of Fót [a town not far from Budapest, the center of the constituency] once in the National Assembly since 2014." This time, the statement of reasons contains a detailed and wellfounded analysis of the factual or opinion-like nature of the statement, in particular with regard to the characteristics of communication during the election campaign.

"[I]n political debates, which are especially heated during the time of the election campaign, statements of fact may not be defined by automatically applying the provability test in the ordinary sense of the word, that is it may not be restricted only to evaluating the verbatim content of the statement examined. To establish the legal liability of those participating in an intensive debate on public affairs, it is not sufficient to show that certain elements of the examined statement may be rebutted objectively. The impugned statement has to be evaluated in the special situation of the election campaign and in the light of its real message for the addressees of the campaign slogans, the message for voters. The approach taken by this evaluation is determined by the fact that, in the democratic debate of public affairs, those who are concerned with the debate are citizens interpreting political events in their own context, who are aware of the specific features of opinions expressed by political parties, especially aware of the special features of campaigning, which are to call attention and have a tendency to exaggerate. [...]

When deciding whether or not, from the constitutional law perspective, the given statement is a fact, all this needs to be taken into account. If the debate of public affairs, especially the specific features of the campaign, is taken into account, it is reasonable to attribute a meaning to the statement according 
to which the voters will interpret this statement as a political opinion of the past or future policy of the party concerned or the aptitude of the candidate and not take it word for word, then this has to be the point of departure in order to ensure the freedom of the most intensive sphere of a public debate." (Paragraphs 28 and 29)

It is clear that, in individual cases, the freedom to debate public affairs and properly differentiating between statements of fact and statements of opinion require a flexible decision, which takes the general state of public speech and the context of the statement into account. In the long run, in election-related questions, it would be worth contemplating whether, in the context of the Act on Electoral Procedure, the analogy of the generally valid rules of personality rights protection is justifiable and applicable to the debate of public affairs, or whether instead, due to the character of an election (referendum) procedure, it is possible to identify specificities which justify a derogation from them. This is not an easy task, because applying the analogy seems natural, as in both cases public figures and public affairs are concerned; what is more, public affairs, which are the most exposed to a strong debate, are a running debate during an election campaign, in which the parties state facts and formulate opinions. Even on this basis, in theory it is possible to interpret the tests of good faith and to exercise rights in accordance with their purpose as prescribed by the Act on Electoral Procedure in a way that is compatible with but not fully identical to the constitutional expectations relating to rules on the protection of the personality rights. One example of a possible derogation could be that even if the necessary due care is given [see 36/1994. (VI. 24.) $\mathrm{AB}$ and 7/2014. (III. 7.) $\mathrm{AB}$, arguments against the protection of stating untrue facts may be raised because, in the context of the election process, they do not result in the violation of personality rights but in misleading voters. ${ }^{29}$

\subsection{Freedom of expression and regulation of political advertising}

Constitutional Court Decision 1/2013. (I. 7.) AB found that the provision in the Act on Electoral Procedure, adopted in 2012 but not published, that political advertising may be published only in public service media during the election campaign period, that is prohibiting this type of political communication in any other media services, is unconstitutional, because it would preclude the political advertising, in precisely the section of the media that reaches the widest audience. The Constitutional Court of Hungary could not find any reason for this restriction that would be compatible with the Fundamental Law (Articles 92-100). ${ }^{30}$ The subsequently adopted new regulation, that is the Act on Electoral Procedure, remedied these constitutional concerns, and the

29 For an analysis of Constitutional Court case-law, see TóTH, J. Zoltán: A véleménynyilvánítási szabadság érvényesülése és érvényesítése a választási eljárásokban: az Alkotmánybíróság gyakorlata a választási ügyben hozott bírói döntéssel szembeni alkotmányjogi panasz alapján indult ügyekben. Jogtudományi Közlöny, 2016/1. 1-18.

30 For an analysis of the decision, see BADó-LovASSY-TÉGLÁsı op. cit. 444-449. 
mandatory complimentary nature of political advertisement has also been inserted in Article IX(3) of the Fundamental Law.

\subsection{Speech rights in Parliament}

The case law of the Constitutional Court also covers the constitutionality of measures restricting Members' freedom of speech in Parliament. ${ }^{31}$ Act XXXVI of 2012 on the National Assembly grants disciplinary powers to the Chairman of a plenary or committee session, in order to maintain the order of parliamentary meetings, ensure the smooth running of sessions and protect the dignity of individuals and communities (Articles 45-52/H).

The legal provisions restricting the right to speak in parliament were addressed in two of the $\mathrm{CCH}$ decisions, which rejected constitutional complaints seeking to establish the unconstitutionality of certain provisions [ 3206/2013. (XI. 18.) AB and 3207/2013. (XI. 18.) $\mathrm{AB}] .{ }^{32}$ With regard to the right of parliamentary speech as the exercise of freedom of speech with a specific purpose and in a specific form, the $\mathrm{CCH}$ established that " $\mathrm{t}]$ he National Assembly is a particularly important venue for the application of freedom of expression, being the terrain where MPs make decisions after lining up arguments and counter-arguments in matters directly affecting the country's destiny" (3206/2013. (XI. 18.) AB, Paragraph 21). However, in connection with the possible restrictions on MPs' freedom of speech, the Panel established as the basis for its argument that "a clear distinction should be made between the freedom of expression and the form of appearance of expression. [...] The National Assembly is entitled to create (self-) restrictive provisions that guarantee the dignity and smooth functioning of the body" [3206/2013. (XI. 18.) AB, Paragraphs 25 and 26]..$^{33}$

\section{Restriction of hate speech}

The legal system addresses the issue of 'hate speech', a term encompassing manifestations of hatred against a community or group of persons, in a complex manner. It is regulated

31 On the human rights nature of the right of Members of Parliament to speak, in the context of Hungarian cases decided by the ECtHR, see SzEnTE, Zoltán: Emberi jogok-e a parlamenti képviselői jogok? A képviselői szólásszabadság alkotmányjogi jellegéröl. Állam-és Jogtudomány, 2015/2. 74-90.

32 On decisions see SMuk, Péter: „Ostrom vagy felújítás alatt?” A véleményszabadság új határai. Közjogi Szemle, 2013/2. 25-34.

33 It should be noted that, in the context of the application of the provisions of the Act on the National Assembly, a number of Hungarian-related ECtHR decisions have been taken which have declared the application of disciplinary measures against Members of Parliament to be contrary to Article 10 of the Convention; see Karácsony and Others v. Hungary, no 42461/13, judgment of 16 September 2014; Szél and Others v. Hungary, no 44357/13, judgment of 16 September 2014, and the 17 May 2016 consolidated decision of the Grand Chamber in the two cases; furthermore see Szanyi v. Hungary, no 35493/13, judgment of 8 November 2016. For an analysis of the Karácsony and Szél cases, see Smuk, Péter: Az Emberi Jogok Európai Bíróságának határozata az Országgyűlés fegyelmi intézkedéseiről. Jogesetek Magyarázata, 2015/1. 63-68.; KAZAI, Viktor Z.: Strasbourgi manifesztum a liberális demokrácia védelmében. Fundamentum, 2015/2-3. 96-106. 
by several criminal statutory elements \{incitement against the community (Criminal Code, Article 332); the use of symbols of authoritarian regimes (Article 335); public denial of the crimes of the National Socialist or Communist regimes (Article 333) and defamation of national symbols (Article 334); the prohibition of incitement to hatred and exclusion in the media regulation [Press Freedom Act, Articles 17(1)-(2)], as well as the private law prohibition set out in the Civil Code [Civil Code, Article 2:54(5)]\}. Four different $\mathrm{CCH}$ decisions adopted between 1992 and 2008 concerning incitement against the community have significantly narrowed the path for legislation ${ }^{34}$ which is presumably why the legislator has become open towards civil law. The ban on the use of symbols of authoritarian regimes and the denial of genocides are, on the whole, more marginal issues in terms of freedom of discussion of public affairs, but their assessment by the $\mathrm{CCH}$ may enrich the constitutional doctrine of freedom of expression with important elements.

\subsection{The Fundamental Law of Hungary and the amendment to the Criminal Code}

Upon its adoption, the Criminal Code made only minor corrections to the former statutory elements of 'hate speech' (in its amended name in the Criminal Code, 'incitement against the community', Article 332). The case-law related to this criminal offence has not increased either, and the $\mathrm{CCH}$ has not adopted any new criminal law hate speech decisions since 2008. On the basis of the first such decision, 30/1992. (V. 26.) $\mathrm{AB}$, hateful expressions that are capable of inciting active, hostile behaviour and anger were punishable for incitement to hatred. The intent of arousing hatred is irrelevant and, for the criminal act to be committed, it is not necessary for the 'incitement' to mobilise 'active hatred' explicitly, but the perpetrator must be aware of the fact that, as a result of their conduct, violent acts might be committed. Later on, the $\mathrm{CCH}$, in its Decisions 18/2004. (V. 25.) AB and 95/2008. (VII. 3.) AB, decided that, similarly to the essence of the clear and present danger doctrine ${ }^{35}$ developed by the Supreme Court of the United States, it exclusively considers the criminal law sanctioning of "acts threatening with the clear and present danger of the violent act and the injury of individual rights" [95/2008. (VII. 3.) AB, Paragraph III(2)(1)] to be constitutionally acceptable. Due to this strict standard, manifestations of hate speech have largely avoided sanction by criminal law.

The Council Framework Decision on combating racism and xenophobia ${ }^{36}$ makes it the responsibility of the Member States of the European Union (EU) to prohibit the incitement of violence or hatred against communities in a uniform manner. Eight years after the adoption of this Framework Decision, the current provisions of the Criminal

34 See Koltay, András: A nagy magyar gyűlöletbeszéd-vita: a „gyülöletre uszítás” alkotmányos mércéjének azonosítása felé. Állam-és Jogtudomány, 2013/1-2. 91-123.

35 See Koltay, András: A „clear and present danger” elv fordulatos története az Egyesült Államokban és Magyarországon. Magyar Jog, 2009/7. 418-423.

36 Council Framework Decision 2008/913/JHA of 28 November 2008 on combating certain forms and expression of racism and xenophobia by means of criminal law. 
Code order the sanctioning, as a result of an amendment to the act in 2016, not only of acts committed against groups but also against members of individual groups, on the grounds of their belonging to the group, and, even more importantly, in addition to 'incitement to hatred' the offending conduct has been supplemented by 'incitement to violence'. If the interpretations which previously evolved in connection with the 'incitement to hatred' are to be applied in the future to the conduct of 'incitement to violence', as indicated in the statement of reasons for the proposed amendment to the Criminal Code, it is questionable how the case-law will interpret it and how it will be separated from 'incitement to violence'.

\subsection{Civil law ban on hate speech}

As the constitutional interpretation of the criminal law ban on hate speech has essentially precluded punishing hate speech, the possibility of introducing a rule in civil law applicable to hate speech had already been raised several times before 2013. ${ }^{37}$ The Civil Code contains a provision to that effect [Article 2:54(5)]. The purpose of these statutory elements is to enable any member of a community to bring an action in the event of an offence against that particular community, relying on the infringement of his personality rights. The Civil Code considers that a "violation of the law that is seriously offensive or unjustifiably offensive in its manner of expression to the general public" as set out in the statutory elements, forming an opinion against a community, may constitute an infringement of an individual's personality rights. This is not a typical application of the system of protection of personality in civil law but, since the individual's violation must be assessed on the basis of objective tests in any case, that is it largely departs from the actual (subjective) injury to the individual seeking redress, it ultimately may be justified to make dogmatic leaps if, in the event of an attack on the community, the law allows the establishment of an injury to an individual belonging to that community. After all, the violation of the individual's personal rights is also protected on the basis of a neutral test, largely separated from his personal characteristics, abilities and situation, which will not necessarily have a close link to him as a plaintiff. Thus, when examining whether an infringement has taken place or not, the court must assess considerations relating to the plaintiff's reliance on the damage to his individual dignity which are similar to those relating to the community as a whole: Whether the communication was able to cause harm (whether the attack on the community was 'permeated' to the individual) or whether it qualifies as a constitutionally protected opinion.

I have written elsewhere in detail about the difficulties of interpreting the Civil Code which also raise constitutional concerns, and summarising them would go beyond the scope of this text. In essence, I maintain that the facts that would provide a basis for

See Koltay, András: A gyülöletbeszéd korlátozása a magyar jogrendszerben. In Koltay, András (ed.): A gyülöletbeszéd korlátozása Magyarországon. Alkotmányos és jogalkalmazói megközelitések, európai kitekintéssel. Budapest, CompLex, 2013. 157-172. 
establishing unconstitutionality are unclear in several areas. ${ }^{38}$ At the same time, it is possible to develop a jurisprudence that strikes the right balance between the competing constitutional rights. The two 'blasphemy' decisions announced on the same day may be considered such decisions.

The background to Decision 6/2021. (II. 19.) AB was a case dating back to 2016, when a demonstration was organised in front of the Polish Embassy in Budapest against the Polish Abortion Act, in which one of the participants, wearing a bishop's costume, invited those present to 'come to Holy Communion', and then, imitating a religious ceremony, placed white pills on the tongues of other participants from a bag clearly labelled 'abortion pill', while intoning 'Body of Christ' (Paragraph 2). The decision of both the Kúria and the Regional Court classified this presentation as belonging to the protected sphere of freedom of expression, but the $\mathrm{CCH}$ annulled their judgments.

The Panel ruled that, although the acts under review appeared to be directed against the Catholic Church, they could have harmed not only members of the Church who were actively engaged in public affairs but also those who did not participate in the public discourse. The protection of the dignity of the ordinary members of a religious community may not be restricted in a manner similar to the restriction of the personal rights of the members of that religious community who act in public. As the $\mathrm{CCH}$ pointed out, even politicians acting in public are entitled to the protection of their personality rights if the value judgement in question concerns their personal or family lives [see 7/2014. (III. 7.) AB]; "similarly, members of religious communities are not obliged to tolerate communications that offend or hurt the beliefs, rituals and practices of their community, as an end in itself, regardless of the discussion of public affairs" [6/2021. (II. 19.) AB, Paragraph 34].

On one important issue, the Panel's reasoning is somewhat debateable: The $\mathrm{CCH}$ criticised the trial courts for not examining the question of whether a performance can be considered an opinion or a discussion of a public affair at all, and this suggestion implicitly raises the possibility of a negative answer (Paragraphs 34-36). In my view, however, a thorough examination of the nature of a performance as an opinion must in any event answer those questions in the affirmative, that is the conduct is located within the boundaries of freedom of expression, from which of course it does not follow that those opinions cannot be restricted.

The starting point of Decision 7/2021. (II. 19.) AB was the front cover of a weekly current affairs magazine, $H V G$ from 2014 Christmas, which bore the title 'Nagy Harácsony' (a wordplay that refers to Christmas and also to scrounging) and featured images of leading politicians' faces superimposed on a modified version of a seventeencentury Dutch painting. The cover image adapted a painting by Gerard von Honthorst, entitled Adoration of the Shepherds, that originally depicted Mary and the new-born

38 See Koltay, András: A gyülölet magánjogi korlátozása. In: Molnár, M. Gábor - Koltay, András (eds.): Bonus iudex. Ünnepi tanulmányok Varga Zoltán 70. születésnapja alkalmából. Budapest, Kúria - PPKE JÁK, 2018. 197-225. For the criticism of the Civil Code, see GÁRdos-Orosz, Fruzsina and PAP, L. András: Gondolatok a gyűlöletbeszéd polgári jogi szabályozásának jogi és jogpolitikai környezetéről. Allam- és Jogtudomány, 2014/2. 3-26.; GÁrdos-Orosz, Fruzsina: Az új polgári jogi gyűlöletbeszédszabályozásról. Fundamentum, 2013/3. 21-38. 
Jesus in the company of shepherds, while the caricature probably have referred to the pursuit of material goods by the government political actors embedded in the picture.

In the case of the $H V G$ front cover page, the Kúria, which made the latest court decision, rejected the application and found that the content in question was protected by freedom of expression and did not violate the personality rights of Christian believers. The Constitutional Court of Hungary upheld the well-foundedness of the set of criteria underlying this decision and accordingly dismissed the constitutional complaint which intended to achieve the annulment of the court ruling. The Panel also saw a political opinion rather than one critical of religion on the front cover (Paragraph 37). It ruled that the content was not intended to offend Christians, and that the use of a system of religious symbols for political expression was not inherently illegal (Paragraph 41). It should be noted, of course, that believers may have been offended, regardless of the nature of the content, which primarily expresses a political opinion, but it does not necessarily follow from the consideration of this criterion that a specific political opinion can be limited.

Constitutional Court Decision 7/2021. (II. 19.) AB notes that the obvious response to offensive or hurtful speech would not primarily be the initiation of litigation but instead more speech, that is reaction to the abuse or beginning a debate (Paragraph 40). I agree with this approach and with the essential reasoning of the two $\mathrm{CCH}$ decisions which aimed to strike a balance between the protection of freedom and dignity. It is an important value in a democracy that individual communities, including churches, are able to enter public life, have their voices heard, take part in debates, and take positions on important issues such as abortion. If the church or its followers exercise their rights to enter the public space, they must also bear consequences that may be detrimental to them. If one takes on a role in public life, one must also tolerate hurtful, offensive and unfounded criticism - and indeed the churches do so, and rightly take a stand on public issues. However, if it also adversely affects the rights of believer who stay away from public life, then restricting freedom of expression is no longer impermissible. The legal assessment of the performance at the demonstration shows the limits of the obligation to tolerate criticism. The cover image cannot be said to have done so much damage compared to it; it can be considered a critique of public actors, and indeed one which is not particularly extreme by the standards of today's public discourse. For the latter, the content was just a tool, rather than the target itself.

The decision on the $H V G$ front cover page may have been preceded by a sharp debate on the Panel, as indicated by the fact that five constitutional judges also attached dissenting opinions to the majority's statement of reasons, that is they would have considered it correct to annul the Kúria's decision. Several of them referred to the detail of the National Creed of the Fundamental Law that refers to the historical role of Christianity. However, the recognition of this role, which is ultimately a fact - a fact that is fundamental to Hungarian statehood - and the protection of critical opinions that violate religious sensitivity are by no means incompatible. As Constitutional Court Judge Schanda notes in his concurring statement of reasons, the front cover image itself provides evidence that Hungary has a Christian culture, because otherwise the content of the image would be incomprehensible [7/2021. (II. 19.) AB, Paragraph 75]. 


\subsection{Prohibition of the use of symbols of authoritarian regimes}

Although Decision 14/2000. (V. 12.) AB declared the factual situation of the Criminal Code establishing the general prohibition on the use of the symbols of authoritarian regimes to be constitutional, after a series of losses before the $\mathrm{ECtHR}^{39}$ the body was called upon to re-evaluate its previous position after a constitutional complaint granted an opportunity for it.

In Decision 4/2013. (II. 21.) AB, the Panel re-examined the constitutionality of Article 269/B of the 1978 Criminal Code (a provision prohibiting the use of symbols of authoritarianism), and this time, contrary to its previous decision, it annulled the statutory elements. The Panel considered that the constitutional assessment of the criminal offence was not made res iudicata in itself simply by virtue of the fact that Decision 14/2000. (V. 12.) AB aimed at this, because the change of circumstances primarily the decision of the ECtHR in Vajnai v. Hungary, and secondly, the established, not fully consistent case-law of criminal courts - allow for a re-examination.

This decision specifies the excessive width of the statutory elements as justification for unconstitutionality:

"The Constitutional Court [...] has established that Article 269/B(1) of the [old, 1978] Criminal Code defines the range of conduct to be punished too broadly, because it fails to differentiate, but instead orders the use of symbols to be punished in general, although it may be inevitable to consider the purpose, the mode of commission or the result obtained for each symbol. The criminalisation of the use of symbols leads to the criminalisation of conducts, the criminalisation of which disproportionately restricts freedom of expression.” [4/2013. (II. 21.) AB, Paragraph V(2)(2)]

The Panel notes that the criminal law restriction on the use of symbols of authoritarian regimes continues to be justified and, in its decision, nearly called on the legislator to create new statutory elements that may now be considered constitutional. This reregulation took place in 2013. Since then, Article 335 of the Criminal Code does not prohibit the use of symbols of authoritarian regimes in general, but only if it is likely to disturb public peace, and a specifically highlighted case of this is the violation of the human dignity or the right to mercy of the victims of dictatorial regimes; that is, the legislature narrows down the applicability of the statutory elements in terms of the manner and result of the offense. ${ }^{40}$

39 See Vajnai v. Hungary, no 33629/06, judgment of 8 July 2008; Fratanoló v. Hungary, no 29459/10, judgment of 3 November 2011; Vajnai v. Hungary (No 2), no 6061/10, judgment of 23 September 2014; Horváth and Vajnai v. Hungary, no 55795/11 and 55798/11, judgment of 23 September 2014; Noé, Vajna and Baló v. Hungary, nos 24515/09, 24539/09 and 24611/09, judgment of 23 September 2014.

40 For an analysis of the Constitutional Court decision, see TótH, J. Zoltán: Az önkényuralmi jelképek használata mint a véleménynyilvánítási szabadság korlátja? Jogelméleti Szemle, 2013/2. 178-196. 


\subsection{Genocide denial}

Prohibiting the denial of the Holocaust and other genocides and crimes against humanity highlights certain serious crimes and tragedies from the fabric of human history and grants special protection against being questioned to the historical facts about them. The European Union Council Framework Decision on Combating Racism and Xenophobia, as mentioned above, ${ }^{41}$ explicitly requires Member States to enact the sanctioning of crimes against humanity or denial of genocide or war crimes. The actual purpose of this decision, that is the prohibition of Holocaust denial, shines through the text, as it specifically mentions the denial or belittling of crimes committed on the grounds of race, colour, religion, ethnic or national origin, as defined by the London Convention of 8 August 1945 after the end of the Second World War, later examined by the Tribunal of Nuremberg, which is to be punished by up to three years' imprisonment in EU Member States. Although the Framework Decision provides for the possibility of evading obligations by referring to the constitutional traditions of a Member State, Hungary first included Holocaust denial in its penal code in 2010, and then, after the amendments to acts rapidly enacted following the parliamentary elections of that year, added denial of genocide or of other acts against humanity committed by the National Socialist or Communist regimes (Criminal Code of 1978, Article 269/C, in the current Criminal Code: Article 333).

In its Decision 16/2013. (VI. 20.) AB, the $\mathrm{CCH}$ did not declare this provision of the Criminal Code of 1978 to be unconstitutional:

"denying the sins of Nazism and Communism shall be considered as abuses of freedom of expression, which severely injures not only the dignity of the community of victims but (also) the dignity of citizens committed to democratic values and identifying with or sympathising with the victims. The protection of the dignity of victims' relatives and persons sympathising with victims makes it possible and/or necessary to foresee a criminal sanction imposed in the event of an act which denies the tragic and historically decisive events that took place in the totalitarian regimes in the twentieth century." (Paragraph 50)

The Panel, similarly to Decision 14/2000. (V. 12.) AB (the first decision on symbols of authoritarian regimes), thus identified the dignity of communities as a protected legal subject, which includes all 'citizens committed to democratic values', and therefore not exclusively victims of the acts identified in the statutory elements, or their relatives. In this way, the $\mathrm{CCH}$ confirmed its case-law which has been evolving since 2000, that is there are special cases beyond the general prohibition of hate speech, which may only be limited subject to strict constitutional guarantees, and these include the statutory elements under review; for the latter, the constitutional protection of freedom of expression may be weaker than in basic cases of hate speech. The link between the statements of reasons for that 2000 decision, already mentioned, and the statement

$41 \quad$ See $n 36$. 
attached to this decision is remarkable in the sense that Decision 4/2013. (II. 21.) AB (the second decision on symbols of authoritarian regimes) overwrote the statement of reasons to its earlier decision of 2000 with regard to the issue examined there, that is in 2013 the Panel itself did not consider its earlier statement of reasons to be sufficient in itself to provide constitutional underpinning for the speech restriction. Nevertheless, the validity of the principle theorem quoted from Decision 16/2013. (VI. 20.) AB ("conduct that violates the dignity of communities and endangers public peace may also be subject to constitutional criminal law restrictions") may be maintained from the decision of 2000 .

In addition to protecting human dignity (that is individual rights), Decision 16/2013. (VI. 20.) AB also considered the protection of public peace to be important. According to the statement of reasons:

"Under twentieth century European totalitarian regimes, the atrocities committed against humanity are considered as unquestionable sins, and treated as evidentiary by all citizens who accept and respect constitutional values, and not only by those who are affected directly or indirectly. Therefore, it is not disputed that any position expressed in public, which is contrary to the above facts and general social beliefs, that violates the sense of justice and the dignity of victims, may also be capable of triggering public outrage, (and) horrifying others, and this could result in the disturbance of public peace. The Constitutional Court established that the conduct ordered to be punished by Article 269/C of the 1978 Criminal Code also implies the risk of disturbing the public peace; the restriction of the public articulation of such opinions and positions is also justified by this circumstance, therefore it is necessary." (Paragraph 52)

The decision avoids a thorough analysis of the question of the principal reason for differentiating certain opinions that fall within the scope of hate speech, that is what justifies their lower level of constitutional protection, compared to the basic case of hate speech. Any 'manifestation of hate speech', and not just in the special cases specified in the legislation, may be equally injurious to the 'community of victims' and to the 'citizens committed to democratic values that join them'. On the other hand, while with regard to Article 269 of the 1978 Criminal Code, the basis for the restriction of opinion would be a serious threat to public peace only in itself, Decision 16/2013. (VI. 20.) AB only mentions the theoretical possibility of disturbing public order, although not as the only theoretical basis for restricting speech. ${ }^{42}$

42 For a discussion of this issue embedded in a European context, see SMUK, Péter: Az önkényuralmi rendszerek jelképei és a használatukat tiltó jogi szankciók rendszere. In Medias Res, 2019/2. 230-252. 


\section{Case-law related to media regulation}

Constitutional Court Decision 165/2011. (XII. 16.) AB subjected several provisions of the Act CIV of 2021 on Press Freedom and Act CLXXXV of 2010 on media services and mass communication to constitutional review (before the entry into force of the Fundamental Law); ${ }^{43}$ however, since 2012, only one procedure has been initiated before the $\mathrm{CCH}$, following a constitutional complaint.

Constitutional Court Decision 3264/2016. (XII. 14.) AB dealt with the constitutional interpretation of a usually marginal rule of media regulation. In addition to the requirement for balanced information, the media regulation also contains requirements on the framework within which the publication of opinions and evaluative explanations intended for presentation in each news and political information program may take place. Articles 12(3) and 12(4) of the Media Services Act serve to enable members of the public to form their position on a given public issue not only in possession of the relevant positions, but also without any interference from the media service provider. A method to achieve this is that persons (reporters, presenters, etc.) who are regularly featured in the media service provider's publicity and current affairs programs, should not include their own opinions and evaluative explanations in the political news, with the exception of when explaining the news. However, that provision does not mean a disproportionate restriction on the publication of individual opinions, since it does not set an absolute ban on the publication of opinions. Article 12(4) of the Media Services Act regulates the relationship between the news published on the media service and opinions and evaluative explanations, the manner of their publication, requiring that if such an opinion (evaluative explanation) is presented, it must be published separately from the news, indicating this subjective quality and identifying the author.

The Media Council of the National Media and Communications Authority established a violation of Articles 12(3) and 12(4) of the Media Services Act, in view of the fact that the newsreader of the media service provider in the case referred to the Jobbik party by using the adjective 'far-right'. The media service provider filed a constitutional complaint against the Kúria's decision that upheld the decision. The Constitutional Court of Hungary found that the Kúria did not apply an interpretation that would unduly restrict the freedom of the press and freedom of expression beyond the statutory limits, and therefore dismissed the complaint [3264/2016. (XII. 14.) AB]. As regards the question of the demarcation of facts and opinions, the $\mathrm{CCH}$ considers that the use of adjectives "with regard to which the social consensus reaches a degree that makes the factual nature unquestionable", may be regarded as a communication of facts. On the other hand, "classifications used by political sciences and common language that do not represent exact categories or indisputable facts generally are of a personal opinion nature" (Paragraphs 47 and 52). Referring to the impact of the use of such modifiers, even if widespread, on public opinion, the Panel stated that "public opinion shows differences from time to time and depending on the circumstances, thus

43 See Koltay, András - Polyák, Gábor: Az Alkotmánybíróság határozata a médiaszabályozás egyes kérdéseiről. Jogesetek Magyarázata, 2012/1. 11-48. 
it is possible to interfere with public opinion, either in a confirming or a weakening direction, by emphasising an adjective, even repeatedly" (Paragraph 56), which can easily undermine credible and objective news services. The statutory requirement clearly does not impose a total ban on commenting on news headlines, and "reporting may be objective even when it transmits an opinion, if it becomes apparent to the listeners that the media content is not identical to the opinion of the news media" (Paragraph 53). When assessing an individual case, the authority or court must in any case take into account the purpose of the legislation and the values to be protected, that is the enforcement of the requirement of authentic and objective information.

The case eventually reached the ECtHR, and the Strasbourg court found, in ATV v. Hungary, ${ }^{44}$ a violation of Article 10 of the Convention, based on the uncertainty of differentiating between facts and opinions, as a result of which the applicant media service provider could not foresee the consequences of its action (Paragraphs 44-55). The statement of reasons seems somewhat contrived, but it is clear that the ECtHR could not pass up the opportunity to criticise the Hungarian media regulation, muchattacked across Europe, when it finally had the opportunity to take a stand on its content, even in such a minor case.

\section{Prohibition of scaremongering}

In the spring of 2020, following the adoption of the bill on 'defence against the Coronavirus', the Criminal Code was also amended, and a second scaremongering statutory element was introduced into the act: "Article 337(2) If someone, during a special legal regime, states or spreads false facts or distorts true facts in a way that is likely to hinder or frustrate the effectiveness of the defence, they shall be punished for a criminal offence by imprisonment for a term of one to five years."

Constitutional Court Decision 15/2020. (VI. 8.) AB found that each of the concepts used by the statutory elements could be attributed a meaning in accordance with the constitutional requirements (Paragraph 43). The decision analyses in detail the requirement of intentional conduct, that is, the range of what exactly the offender's intention must be when disclosing the untrue fact (Paragraph 46). The statement of reasons also addresses in detail the issues of freedom of public debate:

"The prohibition [...] applies only to knowingly untrue (or distorted) statements of fact, not to critical opinions. There is a well-established case-law that these must be included in the circle of protected opinions and, as epidemiology is currently one of our most important public affairs, the strictest protection has to be given to public debates on this subject within the framework of legal norms affecting this subject." (Paragraph 49)

The prohibition pertains only to a specific group of statements of facts. The scope of (untrue) information that could impede the effectiveness of the defence against

44 ATV v. Hungary, no 61178/14, judgment of 28 April 2020. 
the Coronavirus is relatively narrow, at least much narrower than all the published statement of facts in relation to the threat justifying the introduction of a special legal regime. The prohibited action must be objectively capable of hindering or frustrating the effectiveness of the defence, whether undertaken by the government or by other public, municipal or even private actors acting in concert (Paragraphs 53, 60 and 63).

To assist the application of the law, the decision lays down a constitutional requirement for a range of statements of facts and strengthens the protection of freedom of expression. This is the case where the truth of a statement of fact contained in a communication cannot be established at the time of communication, but it may subsequently prove to be false: "[T]he statement of fact can only be punished if it is a statement of a fact that the offender must have known to be false at the time when the act was committed or that he himself distorted and that is capable of hindering or frustrating the defence during the special legal regime" (Operative Part, Article 1). ${ }^{45}$

\section{Capital Market Act and freedom of expression}

Disputed legal situations arising from the disclosure of actual facts may not only occur in the field of protection of personality - even relevant elements of market surveillance rules may affect media freedom. An example of it is the case covered by Decision 3/2015. (IV. 2.) AB. An article published in an online press product, entitled 'Norway can Monitor the Hernádi Case' provided information that a Norwegian state oil fund with a 1.64 per cent stake in MOL Group (an international oil and gas company from Hungary, partly owned by the state) might consider selling its shares. The article also states that the Chairman of MOL Group's Supervisory Board had sold 15,000 out of his earlier nearly 55,000 shares. Due to the article, the MNB, as an authority, initiated an ex officio market surveillance procedure, during which it established that the publisher had violated Act CXX of 2001 on the Capital Market Act prohibiting market influencing. According to the legislation, disclosure, rumour, publication or public communication of unfounded, misleading or false information is considered to influence the market, provided that the person disseminating the information is aware of the false or misleading nature of the information or should have been aware of it with due diligence' [Article 202(d), since then replaced by Regulation (EU) No 596/2014]. In other words, the communication of true factual statements may qualify as market influencing. The decision of the MNB was upheld by the Budapest-Capital Administrative and Labour Court, and the publisher of the press product submitted a constitutional complaint to $\mathrm{CCH}$ for the annulment of the decision, claiming, inter alia, the violation of freedom of expression and the press.

The Constitutional Court of Hungary stated, in connection with the legal provision applied in the case, that those provisions of the Capital Market Act must be interpreted strictly in a manner that does not restrict the press in the performance of its democratic

More on the constitutional interpretation of the facts of scaremongering, as well as on comparing the argumentations in Decisions 18/2000. (VI. 6.) AB and 15/2020. (VI. 8.) AB, see KoltAY, András: A rémhírterjesztés büntethetőségének alkotmányosságáról. In Medias Res, 2020/2. 322-338. 
tasks (Paragraph 26). Given the subject matter of the proceedings, the Panel classified the article as a statement closely related to debates on public affairs, thus classifying it as an expression subject to enhanced protection by freedom of expression and the press (Paragraph 27). With regard to the specific content, the $\mathrm{CCH}$ stated that the "(un)founded, misleading nature of otherwise true (factual) information may only be established in exceptional cases, if the press acts in bad faith" (Paragraph 28). It also stated that the conditions related to the state of consciousness related to the misleading nature and the due care that can be expected "should also be interpreted narrowly, with a content that supports free information" (Paragraph 29). The constitutional problem was not the fact that the court mistakenly classified the content of the article as market influencing, but that it failed to perform the above-mentioned act of discretion. The Panel therefore annulled the judgment of the Court, without prejudice to the decision of the MNB, on the ground of its unconstitutionality. ${ }^{46}$

\section{0. 'Dormant' legislation}

According to a special characteristic of the post-2012 development of law, certain legislation is not applied in practice (or only to a very limited extent). Moreover, some of this 'dormant' legislation overlaps with other statutory provisions. This overgrowth of legislation is confusing, in the absence of practical application or independent content set by case-law.

Even the fourth amendment to the Fundamental Law in 2013 can be said to have played only a minor role in the development of the case-law of the $\mathrm{CCH}$. According to the background material accompanying the draft amendment, Article IX(4) already "raises the earlier case-law of the Constitutional Court to a constitutional level". ${ }^{47}$ By the time the amendment was adopted, the $\mathrm{CCH}$ case-law had developed along these lines, even without the support provided by a legislative text. As mentioned, Article IX(5) aimed to support the private law prohibition of hate speech, which, independently of the issues surrounding the provision in the Civil Code, may be deemed necessary in view of the $\mathrm{CCH}$ 's previous case-law, if the legislator wishes to ensure the constitutionality of a statutory provision.

In the light of the statutory elements of defamation and libel, these two criminal law prohibitions in the Criminal Code aimed at the special regulation of images and sound recordings, namely "making false audio or image recording capable of harming the reputation of another" (Article 226/A) and 'disclosing false audio or image recording capable of harming the reputation of another' (Article 226/B may be considered

46 For a criticism of this decision, see Hörcherné Marosi, Ildikó - Kormányos, Zoltán: Az Alkotmánybíróságnak a Fővárosi Közigazgatási és Munkaügyi Bíróság piacfelügyeleti bírsággal kapcsolatos ügyben hozott ítéletét megsemmisítő döntése. Jogesetek Magyarázata, 2015/3. 5-16 (this analysis mistakenly considers in this case the content published by the press to be commercial speech, which is not covered by the full protection of freedom of expression). For a supporting analysis of the decision in this case see TöRöK, Bernát: Alkotmányjogi tesztek hálójában. A sajtószabadság esete a tökepiaccal. In: FEJES-TöRÖK op. cit. 671-684.

47 Háttéranyag az Alaptörvény negyedik módositásához, see tinyurl.com/5eycz72t, 17. 
redundant). In practice, this special procedure under the Code on Civil Procedure; that is the possibility of bringing an action to enforce the right to an image and a sound recording (Articles 502-504) occurs very rarely.

The case-law of the $\mathrm{CCH}$ - and civil courts - properly secures, even without Article 2:44 of the Civil Code, the freedom of debate on public affairs, and at the same time restricts the enforcement of personal rights by public actors. However, 2018 saw several important legislative amendments which were to fundamentally affect the freedom of debate on public affairs and the enforcement of personality rights in private law. Article 8(1) of Act LIII of 2018 on the Protection of Private Life clarifies that "the purpose of the right to respecting private life is especially the right to a name, the protection of personal data, private secrets, image and sound recording, honour and reputation". Article 7(2), however, stipulates that "private and family life, as well as the home of a public figure, shall be granted the same protection as those of a person who does not qualify as a public figure". Reading the two provisions concurrently, we may be tempted to conclude that the right to reputation and honour, as well as the right to one's image and one's recorded sound, are part of the right to private life and the scope of these rights of public figures are exactly the same as the scope of the rights of private individuals. However, this interpretation is not acceptable; on the one hand - as we have seen in the $\mathrm{CCH}$ case-law - in terms of the enforcement of these rights, the category of primary relevance is not that of the public figure but of the public affair; on the other hand, the same act amended Article 2:44 of the Civil Code, which stipulates that personality rights are restricted in the context of the discussion of public affairs. Nevertheless, the new act does not create a new statement of fact, which may have an impact on the tests of the freedom of speech in the debates of public affairs, and so it remains possible to establish a violation of 'reputation' or 'private life' on the basis of the Civil Code and the case-law of the Constitutional Court and other courts which has evolved on this basis. (In contrast, the act does define individual facts regarding the violation of the right to respect family life, home and maintaining contacts.)

However, under Article 2:44 of the Civil Code, effective since the summer of 2018:

"(1) The exercise of fundamental rights ensuring a free discussion of public affairs may limit the personality rights of public figures to an extent that is necessary and proportionate and is without prejudice to human dignity; however, it shall not violate their private and family life and home.

(2) Public figures shall be entitled to the same protection as non-public figures with regard to communications or conduct falling outside the scope of free discussion of public affairs.

(3) Activities and data in relation to the private or family life of public figures shall not qualify as public affairs."

The new text inserted into Paragraph 1 ("However, it shall not violate their private and family life and home") makes it likely that the text of the Civil Code will lend itself to a more restrictive interpretation of the concept of private life; that is, it does not include the right to reputation and honour. From the whole of Paragraph 1, it remains the case that, in debates of public affairs, the protection of the right to reputation, 
honour, image and recorded sound is restricted and opinions published in these debates which negatively influence these rights are not infringing per se due to their character; they are to be judged by earlier case-law related to the Civil Code and the constitutional interpretation of the freedom of speech. Essentially, the new Paragraph 2 codified part of what is set in Decision 7/2014. (III. 7.) AB, providing the same degree of protection to public figures as for non-public figures in relation to statements falling outside the debate of public affairs. With regard to the new Paragraph 3, it is extremely important that it should be interpreted by the courts in the light of the freedom of speech enshrined in Article IX of the Fundamental Law: The private life of a public figure may also be of high interest to the public if it is related to his public activities or has any bearing on any public affair.

Act LIII of 2018 is a piece of legislation that is difficult to slot reassuringly into the fabric of the legal system, primarily because it mainly repeats certain provisions of the Fundamental Law, the Civil Code, and Act CXII of 2011 on the right to informational self-determination and freedom of information, at some points supplementing them, and ordering the application of the Civil Code regime of sanctions in the event of their violation. Its interpretation and the identification of its independent normative content remain for the courts and the $\mathrm{CCH}$; for the time being, this law is still quietly waiting for its provisions to come into life in practice.

\section{Conclusions}

Some general conclusions may also be drawn from the above review, despite the fact that the $\mathrm{CCH}$ case-law is of necessity constantly evolving. Perhaps sufficient time has passed for the basic approaches to have crystallised from the practice. Below I will make an attempt to draw certain conclusions accordingly.

- The text of the Fundamental Law, including its Fourth Amendment in 2013, only has a moderate effect on the decisions of the $\mathrm{CCH}$. The constitutional content of freedom of expression and of the press of necessity continues to be determined by the decisions handed down by the $\mathrm{CCH}$.

- Decision 7/2014. (III. 7.) AB can boldly be regarded as a 'benchmark decision' on freedom of expression, the general theses of which go beyond the specific constitutional issue raised in that decision. Moreover, this decision may be relevant to case-law, even more so than the pre-2012 case-law, which evolved mostly during abstract norm control procedures, which in several respects determine the theoretical definition of freedom of expression, but which were not able to determine the standards applicable in practice, in a manner compulsory for courts.

- The right to human dignity constitutes the main and most general restriction on freedom of expression, which must be taken into account with due weight in any possible restriction of freedom of expression; the case-law of $\mathrm{CCH}$ avoids previous approaches where, for example, in the case of criminal law defamation or hate speech, the protection of human dignity was not considered a sufficient basis for restricting speech. The case-law of the $\mathrm{CCH}$ aims to strike a balance 
between competing values, mostly successfully in my opinion, despite minor inconsistencies between individual decisions.

- The aspect of constitutional freedom of expression must also be taken into account in private law disputes, even if it is not expressly provided by the text of the Civil Code in that area of law. The most obvious examples of this are cases concerning images of police officers, in which the constitutional approach has almost 'inscribed' the interest of informing the public as an exception to the general rule of consent for the use of an image under the image protection rules set out in the Civil Code. ${ }^{48}$

- In questions linked to the issue of hate speech, that is the prohibition of authoritarian symbols and the denial of genocides, and the private law prohibition of hate speech, the $\mathrm{CCH}$ deviated from its previous standards related to the statutory elements of 'incitement against a community' in the Criminal Code, resulting in a narrowing of the freedom of expression, which is acceptable in view of the increased protection of human dignity.

- On some issues, which are probably not especially important on their own, but which have become symbolic (such as the case of the images of policemen), the $\mathrm{CCH}$ and the courts entered into sharp interpretative disputes, which were obviously decided in favour of the former. This phenomenon can be seen as inevitable birth pangs, leading to the development of a mature case-law of constitutional complaints rather than a dysfunctional constitutional system.

- Since 2012, several statutory rules have been enacted that are not applied in practice or which can even be considered downright unnecessary alongside the other legislative provisions, including an important novelty in the Civil Code, Article 2:44, which envisages greater freedom for debates in public affairs. The existence of rules overlapping with other provisions not applied by the $\mathrm{CCH}$ and the courts is rather confusing.

In my opinion, despite all the above-mentioned major and minor inconsistencies or other problems, significant progress has been made in defining the constitutional content of freedom of expression over the years examined. Debates on public affairs could largely be conducted freely, but in a manner that did not leave human dignity unprotected. The courts have been given clear benchmarks in a number of cases, notably with regard to the protection of personality rights, and the case-law also touches on issues such as rumour or image protection that the $\mathrm{CCH}$ was not permitted to address earlier. Since 2012, the $\mathrm{CCH}$ has renewed its case-law on freedom of expression and made it applicable in the jurisprudence, by basing its activities on the case-law of the two decades that passed since 1992, without hesitating to deviate from it if necessary, even if this deviation has not been easily recognisable in all cases.

48 Regarding the applicability of fundamental rights in private law relations, that is their horizontal scope (Drittwirkung), see GÁrdos-Orosz, Fruzsina: Alkotmányos polgári jog? Az alapvető jogok alkalmazása a magánjogi jogvitákban. Budapest, Dialóg Campus, 2011.; TÉGLÁsı, András: Az alapjogok hatása a magánjogi jogviszonyokban. In: TóTH, J. Zoltán (ed.): A jog többrétegüsége. Budapest, KGRE, 2020. $177-186$. 
In my concluding remarks, I agree with András Schiffer (attorney and former leader of the opposition party LMP), who said that the CCH's "law development activities have stabilised the position of freedom of expression and the press" on the issues affected by the CCH's decisions. "To this extent, paradoxically, the constitutional guarantees of freedom of expression and of the press have become even stronger since 2012." ${ }^{\prime 9}$ In the flurry of polarised public-political debates that occurred in the period under review, this is often insufficiently known, and sometimes outright denied, but certainly a joyous development for the democratic public sphere.

49 SCHIfFer, András: A véleményszabadság alkotmánybírósági esetjoga a megváltozott közjogi környezetben. Alkotmánybirósági Szemle, 2018/1. 48. 
